\title{
Andalusite and Na- and Li-rich cordierite in the La Costa pluton, Sierras Pampeanas, Argentina: textural and chemical evidence for a magmatic origin
}

\author{
Pablo H. Alasino - Juan A. Dahlquist • \\ Carmen Galindo - Cesar Casquet · Julio Saavedra
}

\begin{abstract}
The La Costa pluton in the Sierra de Velasco (NW Argentina) consists of S-type granitoids that can be grouped into three igneous facies: the alkali-rich Santa Cruz facies ( $\mathrm{SCF}, \mathrm{SiO}_{2} \sim 67 \mathrm{wt} \%$ ) distinguished by the presence of andalusite and $\mathrm{Na}$ - and Li-rich cordierite $\left(\mathrm{Na}_{2} \mathrm{O}=1.55-1.77 \mathrm{wt} \%\right.$ and $\left.\mathrm{Li}_{2} \mathrm{O}=0.14-0.66 \mathrm{wt} \%\right)$, the Anillaco facies $\left(\mathrm{SiO}_{2} \sim 74 \mathrm{wt} \%\right.$ ) with a significant proportion of Mn-rich garnet, and the Anjullón facies $\left(\mathrm{SiO}_{2}\right.$ $\sim 75 \mathrm{wt} \%$ ) with abundant albitic plagioclase. The petrography, mineral chemistry and whole-rock geochemistry of the SCF are compatible with magmatic crystallization of $\mathrm{Na}$ - and Li-rich cordierite, andalusite and muscovite from the peraluminous magma under moderate $P-T$ conditions ( $\sim 1.9 \mathrm{kbar}$ and $\mathrm{ca} .735^{\circ} \mathrm{C}$ ). The high $\mathrm{Li}$ content of cordierite in the SCF is unusual for granitic rocks of intermediate composition.
\end{abstract}

P. H. Alasino ( $\square)$

UNLaR, CRILAR-CONICET,

Entre Ríos y Mendoza, 5301 Anillaco, Argentina

e-mail: palasino@crilar-conicet.com.ar

J. A. Dahlquist

UNLaR, CICTERRA-CONICET-UNC,

Av. Vélez Sarsfield 1611, Pab. Geol.,

X5016CGA Córdoba, Argentina

C. Galindo - C. Casquet

Dpto. Petrología y Geoquímica,

UCM, Universidad Complutense, IGE (CSIC),

28040 Madrid, Spain

J. Saavedra

CSIC, Instituto de Agrobiología y Recursos Naturales,

37071 Salamanca, Spain
Keywords Andalusite - Na- and Li-rich cordierite S-type granite - La Costa pluton - Sierras Pampeanas

\section{Introduction}

Andalusite and cordierite are important and common rockforming minerals in metapelitic rocks and may also be abundant in felsic peraluminous igneous rocks such as granites, pegmatites, aplites and rhyolites. A fundamental question concerning the presence of andalusite and cordierite in peraluminous rocks is how they formed, i.e. whether they crystallized from the magma or were trapped as xenocrysts (e.g. Flood and Shaw 1975; Clarke et al. 1976, 2005; Bellido and Barrera 1979; Phillips et al. 1981; Allen and Barr 1983; Weber et al. 1985; Didier and Dupraz 1986; Georget and Fourcade 1988; Clarke 1995; Erdmann et al. 2004; Gottesmann and Förster 2004; Dahlquist et al. 2005). We have focused here on the petrography, mineral chemistry, and the bulk major and trace element composition of the Santa Cruz igneous facies of the La Costa peraluminous granite pluton in the province of La Rioja, NW Argentina, which contains $\mathrm{Na}$ - and $\mathrm{Li}$-rich cordierite, andalusite and muscovite. The occurrence of Na-rich cordierite has been reported in some felsic to highly felsic granitoids $\left(\mathrm{SiO}_{2}\right.$ $>71 \mathrm{wt} \%$, e.g. Erdmann et al. 2004; Villaseca and Barbero 1994). However, the presence of Na-rich cordierite in granitic rocks of relatively low silica contents such as the Santa Cruz igneous facies $\left(\mathrm{SiO}_{2}=65.4-68.6 \mathrm{wt} \%\right)$ has not been found in the literature so far. We provide evidence that supports a magmatic origin for these minerals and evaluate the substitution mechanism that led to this distinctive cordierite composition. Crystallization pressure and temperature values for the La Costa pluton have also been estimated to constrain the physical conditions of 
formation of igneous muscovite, andalusite, and $\mathrm{Na}$ - and Li-rich cordierite.

\section{Geological setting and geochemistry of the La Costa pluton}

The La Costa pluton is a major igneous body in the northeastern part of the Sierra de Velasco (Alasino et al. 2006). Andalusite and Na- and Li-rich cordierite coexist in the Santa Cruz igneous facies, an alkali-rich peraluminous granite with relatively low silica content $\left(\mathrm{SiO}_{2}=65.4\right.$ $68.6 \mathrm{wt} \%$ ), which constitutes the northern part of the pluton (Fig. 1). Alasino et al. (2005) provided a first detailed account of the field relationships, petrography and wholerock chemistry of the Santa Cruz igneous facies. Subsequently, Alasino et al. (2006) recognized two additional granitic igneous facies to the south, the Anjullón and the Anillaco, and proposed that the three igneous facies define a single body, named the La Costa pluton.

The La Costa pluton rocks are two-mica alkali-rich leucocratic monzogranites and alkali feldspar granites, with muscovite always prevalent over biotite, with equigranular texture and medium grain-size $(4-5 \mathrm{~mm})$. They have no visible foliation and sharp contacts against Carboniferous porphyritic monzogranites (with $\mathrm{Pl}-\mathrm{Kfs}-\mathrm{Qtz}-\mathrm{Bt}$ and MsAp-Mon-Zrn as accessories, abbreviations after Kretz 1983) of the Asha pluton and granitic mylonitic rocks (PlKfs-Qtz-Bt-Ms-Grt) of the Tinogasta-Pituil-Antinaco (TIPA) shear zone (López and Toselli 1993; Höckenreiner et al. 2003; Alasino 2007) (Fig. 1b). Each igneous facies of the La Costa pluton is lithologically homogeneous. The modal data are summarized in Table 1 . The Santa Cruz igneous facies is distinguished by the presence of andalusite and Na-and Li-rich cordierite; it has a monzogranitic composition. The Anillaco igneous facies $\left(\mathrm{SiO}_{2} \sim 74 \mathrm{wt} \%\right.$, monzogranite in composition) is distinguished by containing Mn-rich garnet (spessartine between 42 and $48 \%$ of the total molecular composition). The Anjullón igneous facies $\left(\mathrm{SiO}_{2} \sim 75 \mathrm{wt} \%\right)$, an alkali-feldspar granite, is characterized by abundant tourmaline and albite $\left(\mathrm{An}_{1.1}\right)$ (Alasino et al. 2006; Alasino 2007). The parental magmas of La Costa pluton were inferred to have resulted from partial melting of metapelitic protoliths within the TIPA shear zone (Alasino 2007).

The La Costa pluton rocks show relatively high $\mathrm{Al}_{2} \mathrm{O}_{3}$ (13.82-18.01 wt\%), $\mathrm{Na}_{2} \mathrm{O}(3.45-3.93 \mathrm{wt} \%), \mathrm{K}_{2} \mathrm{O}$ (3.97$5.99 \mathrm{wt} \%), \mathrm{P}_{2} \mathrm{O}_{5}(0.27-0.76 \mathrm{wt} \%)$, intermediate to low total iron (1.02-2.28 wt\% $\left.\mathrm{Fe}_{2} \mathrm{O}_{3}\right)$ and low $\mathrm{MgO}(0.03-0.91$ wt\%), $\mathrm{TiO}_{2}(0.02-0.27 \mathrm{wt} \%), \mathrm{MnO}(0.05-0.14 \mathrm{wt} \%)$ and $\mathrm{CaO}$ (0.40-1.17 wt\%) (Alasino et al. 2006; Alasino 2007). They are peraluminous, with ASI [molecular $\mathrm{Al}_{2} \mathrm{O}_{3} /((\mathrm{CaO}-$ $\left.\left.\left.\mathrm{P}_{2} \mathrm{O}_{5}\right)+\mathrm{Na}_{2} \mathrm{O}+\mathrm{K}_{2} \mathrm{O}\right)\right] \geq 1.1$, and are distinctively enriched in some trace elements such as Cs (22-162 ppm), Rb (359-778 ppm), Be (4-22 ppm), Bi (2-216 ppm), Li (137$526 \mathrm{ppm}), \mathrm{U}(4-27 \mathrm{ppm}), \mathrm{Sn}$ (5-43 ppm), W (5-35 ppm), Zn (33-105 ppm), Nb (18-46 ppm), Ga (18-25 ppm) and B (tourmaline in the Anjullón igneous facies can amount to 5 modal \%) (Alasino et al. 2006; Alasino 2007). Moreover, they are depleted in $\mathrm{Cr}, \mathrm{Ni}$, Co and REE (particularly the Anjullón and the Anillaco igneous facies, $\mathrm{R}$ REE $=10-18$ and 20-25 ppm, respectively) (Alasino et al. 2006; Alasino 2007). The Santa Cruz facies shows the highest contents of $\mathrm{TiO}_{2}, \mathrm{Al}_{2} \mathrm{O}_{3}, \mathrm{FeO}, \mathrm{MgO}, \mathrm{CaO}, \mathrm{K}_{2} \mathrm{O}$ and some trace elements such as $\mathrm{Be}, \mathrm{Sr}, \mathrm{Ba}, \mathrm{Zr}$ and REE. Whole-rock chemical analyses of the Santa Cruz igneous facies are summarized in Table 2.

\section{Analytical methods}

Petrographic investigations were conducted on 29 samples. Electron microprobe analyses were determined on two selected samples using a JEOL Superprobe JXA8900-M equipped with five crystal spectrometers at the Luis Brú Electron Microscopy Center, Complutense University, Madrid, Spain. Operating conditions were: acceleration voltage $15 \mathrm{kV}$, probe current $20 \mathrm{nA}$, and
Fig. 1 a Geological sketch map of the Sierras Pampeanas showing the location of the Sierra de Velasco (V). b Studied area showing location of the La Costa pluton and its igneous facies. 1 Santa Cruz igneous facies, 2 Anjullón igneous facies and 3 Anillaco igneous facies (Alasino et al. 2006; Alasino 2007). Dotted line in the Antinaco magmatic complex corresponds to secondary shear zone

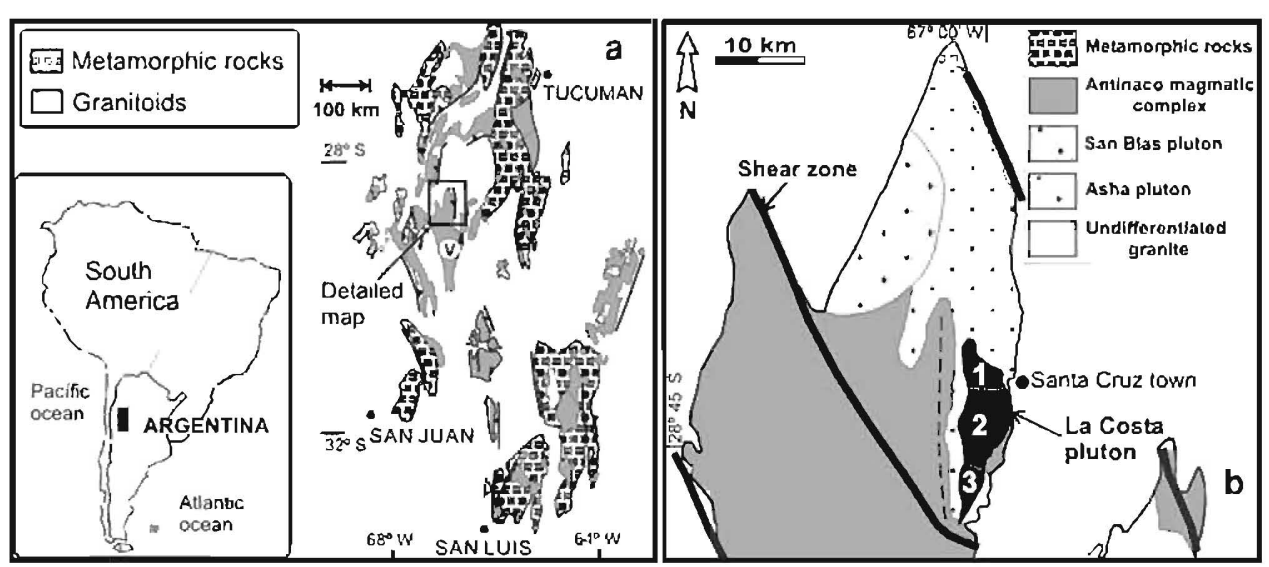


Table 1 Representative modal compositions of the La Costa pluton

\begin{tabular}{|c|c|c|c|}
\hline $\begin{array}{l}\text { Igneous facies } \\
\text { Number of samples } \\
\text { Total points }\end{array}$ & $\begin{array}{l}\text { Santa Cruz } \\
4 \\
991\end{array}$ & $\begin{array}{l}\text { Anillaco } \\
3 \\
903\end{array}$ & $\begin{array}{l}\text { Anjullón } \\
4 \\
815\end{array}$ \\
\hline \multicolumn{4}{|l|}{ Modal \% } \\
\hline Qtz & $27.6 \pm 1.4$ & $36.1 \pm 0.8$ & $43.3 \pm 5.5$ \\
\hline $\mathrm{Kfs}$ & $27.1 \pm 1.0$ & $18.8 \pm 0.9$ & $12.6 \pm 2.6$ \\
\hline P1 & $31.5 \pm 0.6$ & $31.7 \pm 2.6$ & $30.9 \pm 1.9$ \\
\hline $\mathrm{Bt}$ & $3.5 \pm 1.5$ & $2.6 \pm 0.6$ & $1.9 \pm 1.4$ \\
\hline Ms & $6.9 \pm 1.4$ & $7.6 \pm 1.1$ & $7.2 \pm 1.1$ \\
\hline $\mathrm{Crd}$ & $1.5 \pm 0.5$ & - & - \\
\hline Git & - & $2.4 \pm 0.9$ & - \\
\hline And & $0.3 \pm 0.3$ & - & - \\
\hline Tur & $0.5 \pm 0.1$ & $0.3 \pm 0.1$ & $3.3 \pm 1.7$ \\
\hline Ap & $0.4 \pm 0.1$ & $0.2 \pm 0.0$ & $0.5 \pm 0.1$ \\
\hline $\mathrm{Zm}+\mathrm{Mon}$ & $0.4 \pm 0.1$ & $0.1 \pm 0.0$ & $0.1 \pm 0.0$ \\
\hline Opq & $0.3 \pm 0.0$ & $0.2 \pm 0.1$ & $0.2 \pm 0.1$ \\
\hline
\end{tabular}

Mineral abbreviations from Kretz (1983)

beam diameter 1-2 $\mu \mathrm{m}$. Absolute abundances for each element were determined by comparison with known standards (Jarosewich et al. 1980; McGuire et al. 1992), using an on-line ZAF program. Trace elements were determined in Al-rich minerals and micas for two samples using LA-ICP-MS analyses at Granada University, Spain. The LA-ICP-MS analyses were carried out with a NdYAG $213 \mu \mathrm{m}$ Mercantek laser and a torch-shielded quadrupolar Agilent 7500 ICP-MS spectrometer. The laser beam was set a diameter of $60 \mu \mathrm{m}$, with a repetition rate of $10 \mathrm{~Hz}$ and output energy of $1 \mathrm{~mJ}$ per pulse. The ablation time was $60 \mathrm{~s}$ and the spots were pre-abraded for $45 \mathrm{~s}$ with laser output energy of $0.3 \mathrm{~mJ}$ per pulse; ablation was in a He atmosphere. Every analytical session was started and ended with NIST-610, which was also measured every 6-8 spots. To improve detection limits, blanks (with the laser energy set to zero) were recorded before each spot and subtracted from the analytical signal. Data were reduced using home-made software (freely available from F: Bea) written in STATA programing language (Statacorp 2005). This software permits outliers to be identified and discarded, blank subtraction, drift correction, correction for an external standard and conversion to concentration units on an external standard. The precision, calculated as the coefficient of variation $(100 \times$ SD/average $)$ on ten replicates of NIST-6 measured in every session, was about $\pm 3 \%$.

Three samples were chosen for whole-rock chemical analysis, including some major and trace elements (ICPOES at Alex Stewart Assayers, Argentina SA). In addition, two whole-rock analyses from Alasino et al. (2005) were
Table 2 Representative whole rock chemical analyses for the Santa Cruz igneous facies (La Costa pluton)

\begin{tabular}{|c|c|c|c|c|c|}
\hline Sample no. & SVC $-1 a^{a}$ & SVC $-4 a^{a}$ & SVC-104 & SVC $-105^{b}$ & SVC-106 \\
\hline \multicolumn{6}{|l|}{$\mathrm{wt} \%$} \\
\hline $\mathrm{SiO}_{2}$ & 65.36 & 68.62 & & & \\
\hline $\mathrm{TiO}_{2}$ & 0.27 & 0.21 & & & \\
\hline $\mathrm{Al}_{2} \mathrm{O}_{3}$ & 18.01 & 16.82 & 17.38 & 17.19 & 15.82 \\
\hline $\mathrm{Fe}_{2} \mathrm{O}_{3}$ & 2.28 & 1.47 & & 2.27 & 2.97 \\
\hline $\mathrm{MnO}$ & 0.08 & 0.05 & 0.11 & 0.08 & 0.06 \\
\hline $\mathrm{MgO}$ & 0.91 & 0.52 & 0.86 & 0.75 & 0.48 \\
\hline $\mathrm{CaO}$ & 1.17 & 0.93 & 1.35 & 1.21 & 0.90 \\
\hline $\mathrm{Na}_{2} \mathrm{O}$ & 3.45 & 3.52 & 3.49 & 3.57 & 3.22 \\
\hline $\mathrm{K}_{2} \mathrm{O}$ & 5.67 & 5.99 & 5.51 & 5.70 & 6.00 \\
\hline $\mathrm{P}_{2} \mathrm{O}_{5}$ & 0.52 & 0.43 & 0.54 & 0.48 & 0.41 \\
\hline LOI & 1.24 & 0.98 & & & \\
\hline Total & 98.96 & 99.54 & & & \\
\hline \multicolumn{6}{|l|}{ ppm } \\
\hline $\mathrm{Li}$ & & & 180 & 152 & 137 \\
\hline $\mathrm{Be}$ & 22 & 14 & & & \\
\hline $\mathrm{Cs}$ & 49.4 & 47.4 & & & \\
\hline $\mathrm{Rb}$ & 362 & 359 & & & \\
\hline $\mathrm{Sr}$ & 116 & 104 & 123 & 117 & 100 \\
\hline $\mathrm{Ba}$ & 517 & 436 & 472 & 466 & 428 \\
\hline $\mathrm{Zr}$ & 116 & 95.5 & 101 & 99 & 83 \\
\hline $\mathrm{La}$ & 28.4 & 21.1 & 28 & 27 & 22 \\
\hline $\mathrm{Ce}$ & 61.9 & 44.9 & & & \\
\hline Pr & 6.85 & 5.07 & & & \\
\hline $\mathrm{Nd}$ & 26.4 & 19.8 & & & \\
\hline $\mathrm{Sm}$ & 6.32 & 4.69 & & & \\
\hline $\mathrm{Eu}$ & 1.25 & 1.10 & & & \\
\hline $\mathrm{Gd}$ & 5.53 & 4.24 & & & \\
\hline $\mathrm{Tb}$ & 1.05 & 0.79 & & & \\
\hline Dy & 5.49 & 4.28 & & & \\
\hline Ho & 0.95 & 0.76 & & & \\
\hline $\mathrm{Er}$ & 2.55 & 1.99 & & & \\
\hline $\operatorname{Tm}$ & 0.34 & 0.28 & & & \\
\hline $\mathrm{Yb}$ & 1.96 & 1.57 & & & \\
\hline $\mathrm{Lu}$ & 0.29 & 0.23 & & & \\
\hline$\Sigma \mathrm{REE}_{\text {total }}$ & 149 & 111 & & & \\
\hline ASI & 1.42 & 1.30 & 1.35 & 1.31 & 1.27 \\
\hline
\end{tabular}

Total iron as $\mathrm{Fe}_{2} \mathrm{O}_{3} \cdot \mathrm{Al}_{2} \mathrm{O}_{3}, \mathrm{Fe}_{2} \mathrm{O}_{3}, \mathrm{MnO}, \mathrm{MgO}, \mathrm{CaO}, \mathrm{Na}_{2} \mathrm{O}$ and $\mathrm{P}_{2} \mathrm{O}_{5}$ in SVC-104, 105 and 106 were measured as cations and converted into oxides

${ }^{a}$ Data from Alasino et al. (2005) obtained by ICP and ICP-MS at ACTLABS (Canada)

${ }^{b}$ Data obtained by ICP-OES at Alex Stewart Assayers Argentina SA

included in this study (ICP and ICP-MS, following the procedure 4-Lithoresearch code at Activation Laboratories, Ontario, Canada). 


\section{Mineral texture and chemistry of the Santa Cruz} igneous facies

We focus here on the texture and mineral chemistry of andalusite and Na- and Li-rich cordierite of the Santa Cruz igneous facies as well as on biotite and muscovite that probably crystallized in chemical equilibrium with them, and are thus relevant to our interpretation of the crystallization history.

Andalusite

Andalusite is an accessory mineral in the Santa Cruz igneous facies $(<0.6$ modal $\%)$. It is usually found as small $(\leq 1.2 \mathrm{~mm})$ irregular relic grains armored by muscovite either polycrystalline or large single plates (Figs. 2a-c, 3a). Former andalusite crystals were euhedral to subhedral prismatic, with still recognizable cleavage and without chiastolite (carbonaceous material) or mineral inclusions. They show pink to colorless pleochroism. According to the textural classification by Clarke et al. (2005) of andalusite in felsic peraluminous igneous rocks, the Santa Cruz andalusite corresponds to the "single -type" (Figs. 2, 3), i.e. single andalusite grains with or without muscovite pseudomorphs (either mono or polycrystalline).

Electron microprobe analyses of andalusite are shown in Table 3. Some spot locations are shown in Fig. 3a for illustrative purposes. The compositions are very similar to those reported for other andalusites crystallized from a magma (D'Amico et al. 1981; Gordillo et al. 1985; Kawakami 2002; Clarke et al. 2005), i.e. $\mathrm{Al}_{2} \mathrm{O}_{3}$ between 62.90 and $64.26 \mathrm{wt} \%$, and small amounts of $\mathrm{Fe}_{2} \mathrm{O}_{3}(0.42-$ $0.51 \mathrm{wt} \%$ ). An anomalously high $\mathrm{K}_{2} \mathrm{O}$ value of $0.43 \mathrm{wt} \%$ probably resulted from interference with muscovite.

The LA-ICP-MS results are reported in Table 4. Trace element contents are generally low, with $\mathrm{Li}$ (except one of $113 \mathrm{ppm}$ ), Co, Ni, Cu lower than $1 \mathrm{ppm}$ and $\mathrm{Sc}, \mathrm{Cr}, \mathrm{Zn}$ ranging from 1 to $20 \mathrm{ppm}$. The REE contents are below detection limits except for one sample that shows measurable light REE ( $\mathrm{La}, \mathrm{Ce}, \mathrm{Pr}$ and Nd). P, Ga, and V contents are high with range: $71-204,126-168$ and 120 161 ppm, respectively (Table 4; Fig. 4).

Na- and Li-rich cordierite

Cordierite constitutes $1-2 \%$ of the mode. It is often found as medium-grained $(\leq 2.5 \mathrm{~mm})$ euhedral to subhedral crystals with a few random inclusions of zircon, apatite and opaque minerals (mainly $\mathrm{Fe}-\mathrm{Ti}$ oxides). Irregular single grains of cordierite are commonly found armored by polycrystalline muscovite, suggesting subsolidus replacement by the latter mineral (Fig. 3b). In some cases, irregular single grains of cordierite are surrounded by muscovite and biotite and by chlorite after biotite (Fig. 2d). Cordierite and andalusite show a homogeneous distribution in thin section.

Cordierite electron microprobe analysis results are shown in Table 5. Some spot locations are shown in Fig. 3b. The $\mathrm{Al}_{2} \mathrm{O}_{3}$ content (31.64-32.84 wt\%) is high relative to other Na-rich cordierites $\left(1.65 \leq \mathrm{Na}_{2} \mathrm{O} \leq 1.99\right.$ wt $\%$ and $28.2 \leq \mathrm{Al}_{2} \mathrm{O}_{3} \leq 29.5 \mathrm{wt} \%$ ) from pegmatites (Gordillo et al. 1985), but is similar to those from felsic monzogranites (e.g. Villaseca and Barbero 1994; Erdmann et al. 2004). However, the Santa Cruz facies cordierite is remarkably rich in $\mathrm{Na}_{2} \mathrm{O}(1.55-1.77$ wt\%), which is unusual for cordierites from granitic rocks of relatively low silica content (i.e. between 65 and $68 \mathrm{wt} \%$ ). The high $\mathrm{MnO}$ content $(0.85-1.43 \mathrm{wt} \%)$ is also remarkable. Contents of $\mathrm{K}_{2} \mathrm{O}(0.01-0.04 \mathrm{wt} \%)$ and $\mathrm{CaO}(0.01-0.13 \mathrm{wt} \%)$, i.e. elements that enter the hexagonal channels of the structure, are low. The $\mathrm{X}_{\mathrm{Fe}}$ range $(0.39-0.60$, mean of 13 analyses $=0.47$; Table 5 ) is similar to the compositional range reported for other Na-rich cordierites (Gordillo et al. 1985).

LA-ICP-MS data for the Santa Cruz facies cordierite are reported in Table 4 and Fig. 4. These cordierites show remarkably high concentrations of $\mathrm{Li}(654-3,043 \mathrm{ppm})$,
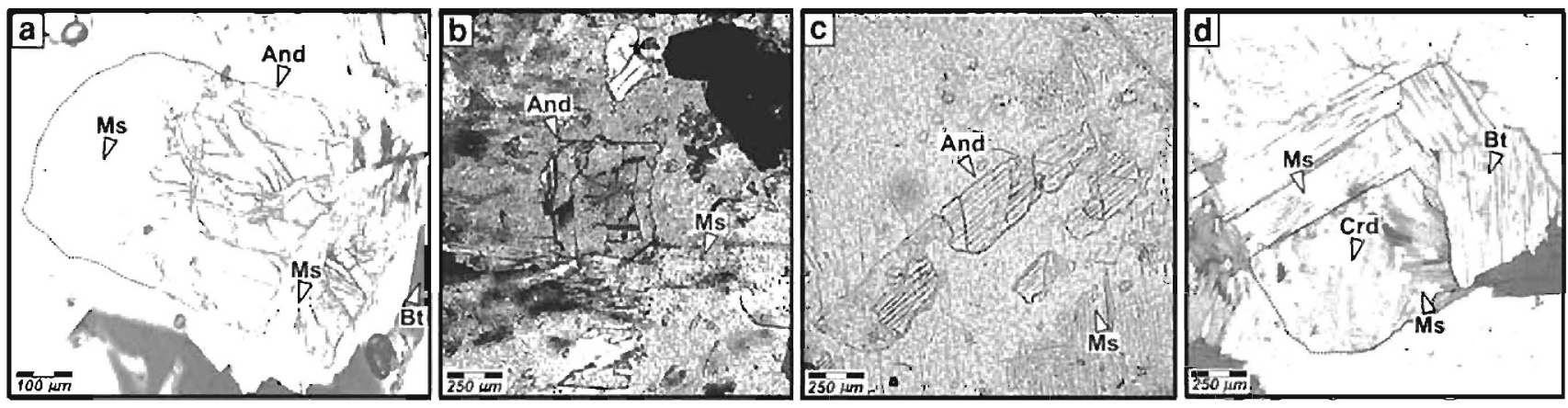

Fig. 2 Photomicrographs showing the textural relationships between andalusite (a-c), Na-rich cordierite (d) and muscovite from Santa Cruz igneous facies, La Costa pluton: abbreviations mineral after Kretz (1983); b and $\mathbf{c}$ taken from Alasino et al. (2005) 
Fig. 3 a, b BSE images with

corresponding sketches $(\mathbf{c}, \mathbf{d})$ showing the location of electron microprobe spots for andalusite, Na-rich cordierite (Tables 3,5), muscovite from the Santa Cruz igneous facies and textural relationships among them. According to Clarke et al. (2005), textural relationships like those shown here are indicative of subsolidus replacement of muscovite after andalusite and $\mathrm{Na}$ - and $\mathrm{Li}$-rich cordierite that resulted in a polycrystalline muscovite pseudomorph. Mineral abbreviations after Kretz (1983)

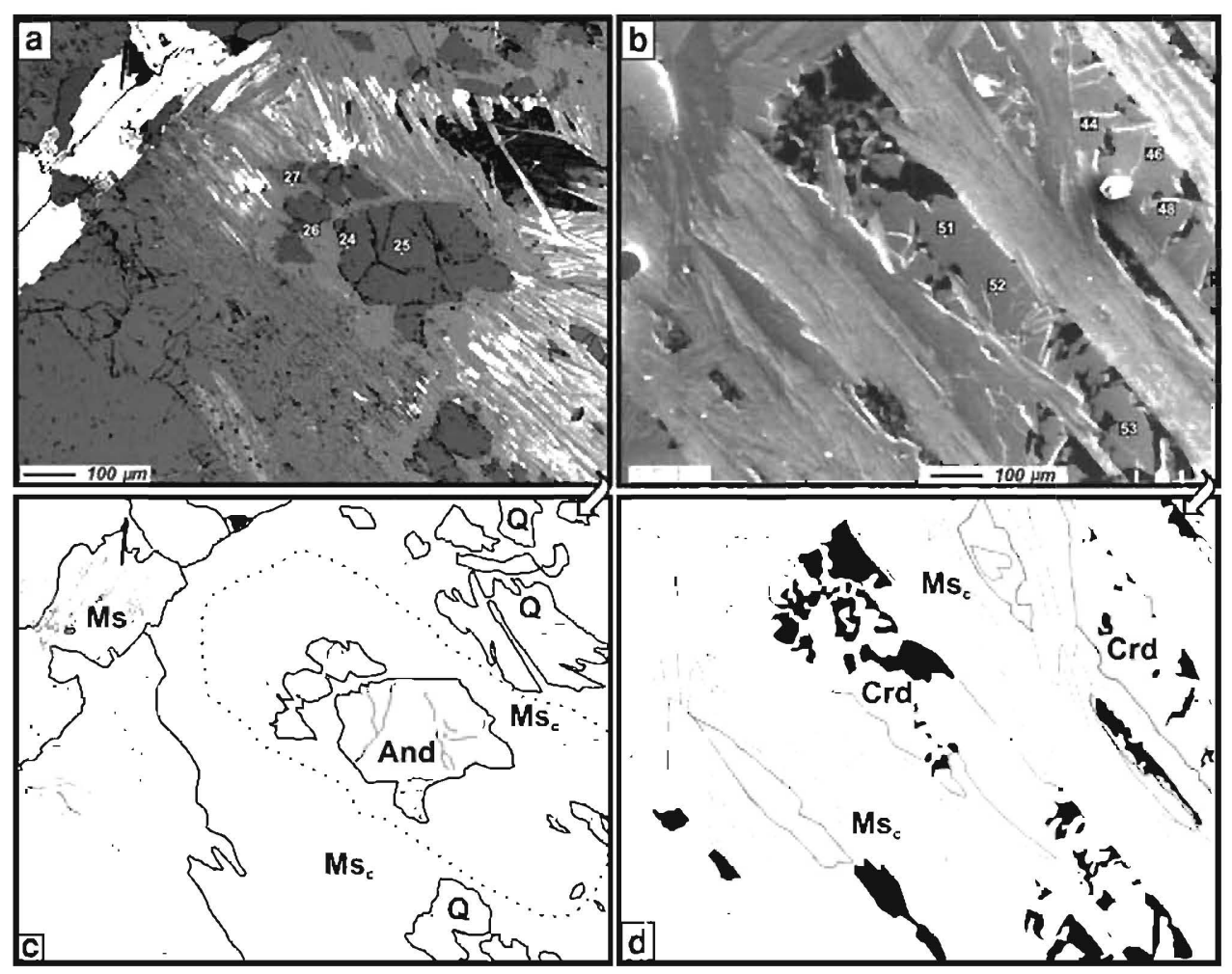

$\mathrm{Rb}$ (7-678 ppm), Zr (9-463 ppm), Cs (162-442 ppm) and Be $(82-1,878 \mathrm{ppm})$. Other trace element contents are: Zn (85-310 ppm), Ba (10-233 ppm), Cu (5-145 ppm), P (20-104 ppm), Ga (19-59 ppm), Sr (3-48 ppm) and Hf (5-42 ppm). Elements such as Sc, V, Cr, Co, Ni, Ta, Pb, $\mathrm{Tl}, \mathrm{U}, \mathrm{Y}, \mathrm{Nb}$ and $\mathrm{Th}$ are in most cases well below $15 \mathrm{ppm}$. The total REE content is low $(<19.1 \mathrm{ppm})$; intermediate and heavy REE contents are in most cases below the detection limit.

Substitution mechanisms in Na- and $\mathrm{Li}$-rich cordierite

Several authors (e.g. London 1995; Černý et al. 1997; Evensen and London 2003; Bertoldi et al. 2004) pointed out that $\mathrm{Be}$ and $\mathrm{Li}$ can be significantly fractionated in cordierite $\left(D_{\mathrm{Li}}^{\mathrm{Crd} / \mathrm{melt}}=125 \pm 3.7\right.$ and $D_{\mathrm{Be}}^{\mathrm{Crd} / \mathrm{melt}}=29.1 \pm 2.1$; Bea et al. 1994) coincident with coupled $\mathrm{Na}+$ substitution (Gordillo et al. 1985; Schreyer 1985; Bertoldi et al. 2004 and references therein). In fact, the high contents of $\mathrm{Li}$ ( 0.18 a.p.f.u.) and $\mathrm{Na}(0.32-0.37$ a.p.f.u.) (Table 5) found in cordierite from the Santa Cruz igneous facies correlate well with the low octahedral site occupancy by divalent cations $\left(\Sigma \mathrm{Mg}+\mathrm{Fe}^{2+}+\mathrm{Mn}=1.73\right.$ a.p.f.u., average from 13 electron microprobe analyses; Table 5). This evidence suggests that incorporation of $\mathrm{Li}$ in cordierite probably resulted from the following coupled substitution (Schreyer 1985) as evidenced in Fig. 5:
$\mathrm{Ch}_{\mathrm{Na}^{+}}+{ }^{\mathrm{VI}} \mathrm{Li}^{+}={ }^{\mathrm{Ch}}[]+{ }^{\mathrm{V}} \mathrm{Mg}^{2+}$.

The introduction of $\mathrm{Na}^{+}$in the hexagonal channels of the cordierite crystal structure would involve coupled introduction of $\mathrm{Li}^{+}$in the octahedral site, replacing divalent cations. Moreover, the high content of $\mathrm{Be}$ in the Santa Cruz facies cordierite $(82-1,879 \mathrm{ppm})$ suggests a coupled substitution (Černý and Povondra 1966) of the type:

${ }^{\mathrm{Ch}} \mathrm{Na}^{+}+{ }^{\mathrm{IV}} \mathrm{Be}^{2+}={ }^{\mathrm{Ch}}[]+{ }^{\mathrm{IV}} \mathrm{Al}^{3+}$.

The high content of Cs in the Santa Cruz facies cordierite $(162-442 \mathrm{ppm})$ is also noticeable. Fractionation of Cs into magmatic cordierite $\left(D_{\mathrm{Cs}}^{\mathrm{Crd}}=31.5 \pm 1.6\right.$; Bea et al. 1994) has in fact been invoked by several authors (e.g. London 1995; Černý et al. 1997; Evensen and London 2003; Bertoldi et al. 2004).

\section{Biotite}

Biotite is medium-grained $(\sim 2.8 \times 1.6 \mathrm{~mm})$ euhedral to subhedral, with light- to dark-brown pleochroism. Occasionally small crystals of zircon, monazite and apatite were observed as inclusions.

In terms of $\mathrm{Al}^{\mathrm{IV}}$ versus $\mathrm{Fe}^{2+} /\left(\mathrm{Fe}^{2+}+\mathrm{Mg}\right)$, biotite from the Santa Cruz igneous facies shows high siderophylliteeastonite contents and intermediate $\mathrm{Fe}^{2+} /\left(\mathrm{Fe}^{2+}+\mathrm{Mg}\right)$ ratios between 0.55 and 0.57 (Table 6). Biotite has a 
Table 3 Representative composition of the Santa Cruz igneous facies andalusite

\begin{tabular}{|c|c|c|c|c|c|c|}
\hline \multirow{2}{*}{$\begin{array}{l}\text { Mineral } \\
\text { Analysis no. }\end{array}$} & \multicolumn{2}{|c|}{ Andalusite 1} & \multicolumn{4}{|c|}{ Andalusite 2} \\
\hline & 24 & 25 & 59 & 41 & 58 & 60 \\
\hline \multicolumn{7}{|l|}{ wt\% } \\
\hline $\mathrm{SiO}_{2}$ & 35.75 & 35.37 & 36.97 & 37.28 & 37.43 & 37.82 \\
\hline $\mathrm{Al}_{2} \mathrm{O}_{3}$ & 64.26 & 63.21 & 63.87 & 63.64 & 63.65 & 62.90 \\
\hline $\mathrm{TiO}_{2}$ & 0.04 & 0.05 & 0.05 & bdl & 0.03 & 0.08 \\
\hline $\mathrm{Fe}_{2} \mathrm{O}_{3}$ & 0.47 & 0.51 & 0.46 & 0.50 & 0.46 & 0.42 \\
\hline $\mathrm{MnO}$ & bdl & 0.01 & bdl & bdl & bdl & bdl \\
\hline $\mathrm{MgO}$ & 0.01 & 0.04 & 0.06 & bdl & 0.01 & 0.03 \\
\hline $\mathrm{CaO}$ & bdl & 0.01 & 0.01 & bdl & 0.02 & 0.02 \\
\hline $\mathrm{Na}_{2} \mathrm{O}$ & bdl & bdl & bdl & bdl & bdl & 0.02 \\
\hline $\mathrm{K}_{2} \mathrm{O}$ & 0.03 & 0.01 & 0.03 & 0.02 & 0.05 & 0.43 \\
\hline $\mathbf{F}$ & bdl & 0.03 & bdl & 0.03 & 0.02 & 0.03 \\
\hline $\mathrm{Cl}$ & bdl & bdl & bdl & bdl & bdl & 0.01 \\
\hline Total & 100.56 & 99.24 & 101.45 & 101.47 & 101.67 & 101.76 \\
\hline \multicolumn{7}{|c|}{ Structural formulae calculated on the basis of $20 \mathrm{O}$} \\
\hline $\mathrm{Si}$ & 3.85 & 3.86 & 3.94 & 3.97 & 3.98 & 4.03 \\
\hline $\mathrm{Al}$ & 8.15 & 8.13 & 8.02 & 7.99 & 7.97 & 7.89 \\
\hline $\mathrm{Ti}$ & 0.00 & 0.00 & 0.00 & 0.00 & 0.00 & 0.01 \\
\hline $\mathrm{Fe}^{3+}$ & 0.04 & 0.04 & 0.04 & 0.04 & 0.04 & 0.03 \\
\hline $\mathrm{Mn}$ & 0.00 & 0.00 & 0.00 & 0.00 & 0.00 & 0.00 \\
\hline $\mathrm{Mg}$ & 0.00 & 0.01 & 0.01 & 0.00 & 0.00 & 0.01 \\
\hline $\mathrm{Ca}$ & 0.00 & 0.00 & 0.00 & 0.00 & 0.00 & 0.00 \\
\hline $\mathrm{Na}$ & 0.00 & 0.00 & 0.00 & 0.00 & 0.00 & 0.01 \\
\hline $\mathrm{K}$ & 0.03 & 0.01 & 0.02 & 0.05 & 0.03 & 0.43 \\
\hline
\end{tabular}

Total iron measured as $\mathrm{FeO}$ and expressed as $\mathrm{Fe}_{2} \mathrm{O}_{3}$. Andalusite 1 and 2 correspond to different analyzed mineral grains

$b d l$ below detection limit

consistently high $\mathrm{Al}^{\mathrm{IV}}$ content (2.56-2.66 a.p.f.u.; Table 6). The LA-ICP-MS analyses of biotite reveal high concentrations of $\mathrm{Li}(609-1,032 \mathrm{ppm})$, Cs (44-877 ppm), Zn (260$673 \mathrm{ppm}), \mathrm{V}(49-407 \mathrm{ppm})$ and $\mathrm{Nb}(96-313 \mathrm{ppm})$, with lower concentrations of $\mathrm{Cr}(\leq 136 \mathrm{ppm}), \mathrm{Ga}(\leq 64 \mathrm{ppm})$, Ta ( $\leq 58 \mathrm{ppm}), \mathrm{Sc}(\leq 33 \mathrm{ppm}), \mathrm{Co}(\leq 31 \mathrm{ppm}), \mathrm{Ni}(\leq 26 \mathrm{ppm})$, $\mathrm{Tl}(\leq 11 \mathrm{ppm}), \mathrm{Be}(\leq 8 \mathrm{ppm}), \mathrm{Pb}(\leq 4 \mathrm{ppm})$ and low concentrations of $\mathrm{Cu}, \mathrm{U}$, Th, Hf ( $\leq 2$ ppm; Table 7 ; Fig. 4). The REE total content is low ( $<8.7 \mathrm{ppm}$; Table 7$)$.

\section{Muscovite}

Care was taken to distinguish between primary and secondary muscovite. Primary muscovite is widely held to be an indicator of peraluminous magmas (Speer 1984). Petrographic evidence and chemical data suggest that both types of muscovite are present in the Santa Cruz igneous facies.

Chemical analyses of texturally primary muscovite (see Table 6), i.e. medium-grained $\sim 3.2 \times 1.9 \mathrm{~mm}$, euhedral
Table 4 Representative LA-ICP-MS analyses of the Santa Cruz igneous facies Al-rich minerals

\begin{tabular}{|c|c|c|c|c|c|c|c|}
\hline \multirow{2}{*}{$\begin{array}{l}\text { Mineral } \\
\text { Analysis no. }\end{array}$} & \multicolumn{3}{|c|}{ Andalusite } & \multicolumn{2}{|c|}{ Cordierite 1} & \multicolumn{2}{|c|}{ Cordierite 2} \\
\hline & 23 & 24 & 25 & 7 & 8 & 31 & 32 \\
\hline \multicolumn{8}{|l|}{ ppm } \\
\hline $\mathrm{Li}$ & 0.95 & 1.01 & 113 & 3,042 & 2,978 & 1,236 & 654 \\
\hline $\mathrm{Be}$ & bdl & 0.04 & 0.64 & 205 & 1,878 & 82.0 & 86.5 \\
\hline $\mathrm{Cs}$ & bdl & bdl & bdl & 161 & 229 & 442 & 281 \\
\hline $\mathrm{P}$ & 132 & 204 & 71.2 & 18.9 & 103 & 94.5 & 49.1 \\
\hline $\mathrm{Sc}$ & 2.93 & 2.39 & 1.38 & 2.34 & 2.23 & 3.21 & 1.75 \\
\hline V & 160 & 160 & 119 & 0.85 & 0.90 & 4.38 & 1.93 \\
\hline $\mathrm{Cr}$ & 7.57 & 16.9 & 18.3 & 5.66 & bdl & 3.76 & bdl \\
\hline Co & 0.36 & 0.30 & 0.21 & 9.88 & 4.64 & 15.0 & 8.40 \\
\hline $\mathrm{Ni}$ & 0.44 & 0.67 & 0.46 & 2.88 & 4.23 & 11.8 & 4.28 \\
\hline $\mathrm{Cu}$ & 0.13 & 0.07 & 0.13 & 0.62 & 4.96 & 144 & 20.2 \\
\hline $\mathrm{Zn}$ & 8.95 & 9.79 & 5.28 & 171 & 84.7 & 310 & 238 \\
\hline $\mathrm{Ga}$ & 167 & 163 & 125 & 51.9 & 58.9 & 16.8 & 43.8 \\
\hline $\mathrm{Rb}$ & 0.07 & 0.02 & bdl & 7.44 & 146 & 413 & 678 \\
\hline $\mathrm{Sr}$ & bdl & bdl & bdl & 3.41 & 8.75 & 48.4 & 10.7 \\
\hline $\mathrm{Y}$ & bdl & bdl & bdl & 0.45 & 0.72 & 5.80 & 1.06 \\
\hline $\mathrm{Zr}$ & bdl & 0.03 & 0.14 & 13.0 & 8.67 & 462 & 64.3 \\
\hline $\mathrm{Nb}$ & bdl & 0.02 & bdl & 0.13 & 0.11 & 2.36 & 0.66 \\
\hline $\mathrm{Ba}$ & bdl & 0.04 & 0.02 & 10.0 & 134 & 163 & 232 \\
\hline $\mathrm{Hf}$ & bdl & bdl & bdl & 0.02 & bdl & 42.0 & 5.15 \\
\hline $\mathrm{Ta}$ & bdl & bdl & bdl & bdl & bdl & 1.76 & 0.24 \\
\hline $\mathrm{T} 1$ & bdl & bdl & bdl & 0.11 & 1.25 & 2.51 & 4.69 \\
\hline $\mathrm{Pb}$ & bdl & bdl & bdl & 1.22 & 4.10 & 16.5 & 4.77 \\
\hline Th & bdl & bdl & bdl & 0.17 & 0.12 & 0.79 & 0.07 \\
\hline $\mathrm{U}$ & bdl & bdl & 0.05 & 0.23 & 0.60 & 6.46 & 1.20 \\
\hline \multicolumn{8}{|l|}{ REE (ppm) } \\
\hline $\mathrm{La}$ & bdl & bdl & 0.17 & 0.08 & bdl & 3.83 & 0.84 \\
\hline $\mathrm{Ce}$ & bdl & bdl & 0.22 & 0.10 & 1.07 & 5.91 & 1.42 \\
\hline Pr & bdl & bdl & 0.04 & 0.12 & 0.13 & 0.81 & 0.17 \\
\hline $\mathrm{Nd}$ & bdl & bdl & 0.16 & 0.07 & bdl & 3.60 & 0.74 \\
\hline $\mathrm{Sm}$ & bdl & bdl & bdl & bdl & 0.09 & 0.96 & 0.07 \\
\hline $\mathrm{Eu}$ & bdl & bdl & bdl & bdl & 0.05 & 0.28 & 0.10 \\
\hline $\mathrm{Gd}$ & bdl & bdl & bdl & bdl & bdl & 0.96 & 0.07 \\
\hline $\mathrm{Tb}$ & bdl & bdl & bdl & bdl & bdl & 0.16 & bdl \\
\hline Dy & bdl & bdl & bdl & bdl & bdl & 1.01 & bdl \\
\hline Ho & bdl & bdl & bdl & bdl & bdl & 0.22 & bdl \\
\hline $\mathrm{Er}$ & bdl & bdl & bdl & bdl & bdl & 0.60 & bdl \\
\hline $\operatorname{Tm}$ & bdl & bdl & bdl & bdl & bdl & 0.09 & bdl \\
\hline $\mathrm{Yb}$ & bdl & bdl & bdl & 0.27 & bdl & 0.55 & bdl \\
\hline $\mathrm{Lu}$ & bdl & bdl & bdl & 0.02 & bdl & 0.09 & bdl \\
\hline
\end{tabular}

Cordierite 1 and 2 correspond to different analyzed mineral grains $b d l$ below detection limit

crystals, plot in the expected compositional field on a $\mathrm{Mg}-$ Ti-Na diagram (Fig. 6a) according to the criteria of Miller et al. (1981). Moreover, primary muscovite in the Santa 
Table 5 Representative microprobe analyses of the Santa Cruz igneous facies cordierite

\begin{tabular}{|c|c|c|c|c|c|c|c|c|c|c|c|c|c|c|}
\hline \multirow{2}{*}{$\begin{array}{l}\text { Mineral } \\
\text { Analysis no. }\end{array}$} & \multicolumn{2}{|c|}{ Cordierite 1} & \multicolumn{11}{|c|}{ Cordierite 2} & \multirow{2}{*}{$\begin{array}{l}\mathrm{Crd}^{\mathrm{a}} \\
\mathrm{Av}\end{array}$} \\
\hline & 30 & 31 & 44 & $44^{\prime}$ & 45 & 46 & 47 & 48 & 49 & 50 & 51 & 52 & 54 & \\
\hline \multicolumn{15}{|l|}{ wt\% } \\
\hline $\mathrm{SiO}_{2}$ & 47.49 & 47.61 & 47.01 & 46.82 & 47.05 & 47.50 & 46.88 & 48.18 & 47.58 & 46.12 & 47.45 & 48.04 & 48.10 & 47.37 \\
\hline $\mathrm{Al}_{2} \mathrm{O}_{3}$ & 32.82 & 32.67 & 31.97 & 31.74 & 32.49 & 32.54 & 32.23 & 32.18 & 32.72 & 31.64 & 32.92 & 32.68 & 32.68 & 32.41 \\
\hline $\mathrm{TiO}_{2}$ & bdl & bdl & bdl & bdl & bdl & bdl & bdl & bdl & 0.04 & 0.01 & 0.02 & 0.03 & bdl & 0.01 \\
\hline $\mathrm{FeO}$ & 7.01 & 6.85 & 9.88 & 9.86 & 9.95 & 7.27 & 6.98 & 6.49 & 9.63 & 9.00 & 7.57 & 6.69 & 6.76 & 8.00 \\
\hline $\mathrm{MnO}$ & 0.90 & 1.38 & 0.89 & 0.95 & 0.85 & 1.29 & 1.43 & 1.43 & 0.97 & 1.27 & 0.92 & 1.21 & 0.97 & 1.11 \\
\hline $\mathrm{MgO}$ & 5.82 & 5.77 & 4.08 & 3.71 & 4.27 & 5.42 & 5.34 & 5.70 & 4.41 & 4.44 & 5.34 & 5.60 & 5.85 & 5.06 \\
\hline $\mathrm{CaO}$ & 0.01 & 0.04 & 0.08 & 0.05 & 0.13 & 0.07 & 0.11 & 0.07 & 0.07 & 0.10 & 0.03 & 0.06 & 0.05 & 0.07 \\
\hline $\mathrm{Na}_{2} \mathrm{O}$ & 1.58 & 1.55 & 1.67 & 1.64 & 1.74 & 1.64 & 1.76 & 1.75 & 1.70 & 1.77 & 1.65 & 1.70 & 1.63 & 1.68 \\
\hline $\mathrm{K}_{2} \mathrm{O}$ & 0.01 & bdl & 0.04 & bdl & 0.04 & bdl & 0.03 & 0.01 & bdl & 0.01 & bdl & 0.01 & 0.03 & 0.01 \\
\hline F & bdl & bdl & bdl & 0.01 & bdl & bdl & bdl & bdl & bdl & 0.01 & bdl & bdl & bdl & bdl \\
\hline $\mathrm{Cl}$ & bdl & bdl & bdl & bdl & bdl & 0.01 & bdl & bdl & bdl & 0.01 & bdl & bdl & bdl & bdl \\
\hline $\mathrm{Li}_{2} \mathrm{O}^{\mathrm{b}}$ & nd & nd & nd & nd & nd & nd & nd & nd & nd & nd & nd & nd & nd & 0.43 \\
\hline $\mathrm{BeO}^{\mathrm{b}}$ & nd & nd & nd & nd & nd & nd & nd & nd & nd & nd & nd & nd & nd & 0.16 \\
\hline Total & 95.64 & 95.87 & 95.62 & 94.78 & 96.52 & 95.74 & 94.76 & 95.81 & 97.12 & 94.38 & 95.90 & 96.02 & 96.07 & 96.30 \\
\hline \multicolumn{15}{|c|}{ Structural formulae calculated on the basis of 180} \\
\hline $\mathrm{Si}$ & 5.03 & 5.04 & 5.05 & 5.08 & 5.02 & 5.04 & 5.03 & 5.09 & 5.03 & 5.02 & 5.03 & 5.07 & 5.07 & 5.01 \\
\hline $\mathrm{Al}^{\mathrm{IV}}$ & 3.97 & 3.96 & 3.95 & 3.92 & 3.98 & 3.96 & 3.97 & 3.91 & 3.97 & 3.98 & 3.97 & 3.93 & 3.93 & 3.95 \\
\hline $\mathrm{Be}$ & & & & & & & & & & & & & & 0.04 \\
\hline Sum-T & 9.00 & 9.00 & 9.00 & 9.00 & 9.00 & 9.00 & 9.00 & 9.00 & 9.00 & 9.00 & 9.00 & 9.00 & 9.00 & 9.000 \\
\hline $\mathrm{Al}^{\mathrm{VI}}$ & 0.13 & 0.11 & 0.10 & 0.13 & 0.09 & 0.12 & 0.11 & 0.10 & 0.11 & 0.08 & 0.13 & 0.13 & 0.12 & 0.16 \\
\hline $\mathrm{Ti}$ & 0.00 & 0.00 & 0.00 & 0.00 & 0.00 & 0.00 & 0.00 & 0.00 & 0.00 & 0.00 & 0.00 & 0.00 & 0.00 & 0.00 \\
\hline $\mathrm{Fe}^{2+}$ & 0.62 & 0.61 & 0.89 & 0.89 & 0.89 & 0.65 & 0.63 & 0.57 & 0.85 & 0.82 & 0.67 & 0.59 & 0.60 & 0.62 \\
\hline Mn & 0.08 & 0.12 & 0.08 & 0.09 & 0.08 & 0.12 & 0.13 & 0.13 & 0.09 & 0.12 & 0.08 & 0.11 & 0.09 & 0.08 \\
\hline $\mathrm{Mg}$ & 0.92 & 0.91 & 0.65 & 0.60 & 0.68 & 0.86 & 0.85 & 0.90 & 0.69 & 0.72 & 0.84 & 0.88 & 0.92 & 0.92 \\
\hline $\mathrm{Li}$ & & & & & & & & & & & & & & 0.18 \\
\hline Sum-B & 1.75 & 1.75 & 1.72 & 1.71 & 1.74 & 1.75 & 1.72 & 1.70 & 1.74 & 1.74 & 1.72 & 1.71 & 1.73 & 1.96 \\
\hline $\mathrm{Ca}$ & 0.00 & 0.00 & 0.01 & 0.01 & 0.02 & 0.01 & 0.01 & 0.01 & 0.01 & 0.01 & 0.00 & 0.01 & 0.01 & 0.00 \\
\hline $\mathrm{Na}$ & 0.32 & 0.32 & 0.35 & 0.34 & 0.36 & 0.34 & 0.37 & 0.36 & 0.35 & 0.37 & 0.34 & 0.35 & 0.33 & 0.33 \\
\hline K & 0.00 & 0.000 & 0.01 & 0.00 & 0.01 & 0.00 & 0.00 & 0.00 & 0.00 & 0.00 & 0.00 & 0.00 & 0.00 & 0.00 \\
\hline Sum-A & 0.32 & 0.32 & 0.37 & 0.35 & 0.39 & 0.35 & 0.38 & 0.37 & 0.36 & 0.38 & 0.34 & 0.36 & 0.34 & 0.33 \\
\hline $\mathrm{Fe} /(\mathrm{Fe}+\mathrm{Mg})$ & 0.40 & 0.40 & 0.58 & 0.60 & 0.57 & 0.43 & 0.42 & 0.39 & 0.55 & 0.53 & 0.44 & 0.40 & 0.39 & 0.47 \\
\hline
\end{tabular}

Total iron measured as $\mathrm{FeO}$. Cordierite 1 and 2 correspond to different analyzed mineral grains

bdl below detection limit; nd not determined

${ }^{a}$ Corresponds to the average of the analysis of cordierite using the data obtained from electron microprobe (this table) and the data obtained from LA-ICP-MS (Table 4)

b Data obtained from the average of $\mathrm{Li}$ and Be from Table 4 and converted into oxides

added to the magma from metamorphic country rock (e.g. Ugidos and Recio 1993; Stimac et al. 1995; Gottesmann and Förster 2004).

1. Field evidence Andalusite and cordierite were only found in the Santa Cruz igneous facies, i.e. they are absent in the other two igneous facies of the La Costa pluton, suggesting that both minerals crystallized from the Santa Cruz facies magma. The La Costa pluton was emplaced within undeformed biotite porphyritic granites of the Asha pluton and granitic mylonites of the Antinaco magmatic complex (Fig. 1b). Moreover, metamorphic rocks are not found in the area and metamorphic xenoliths are absent from all three facies of the La Costa pluton (Fig. 1b). Thus, there is no field evidence for a local metamorphic origin of andalusite and cordierite. 


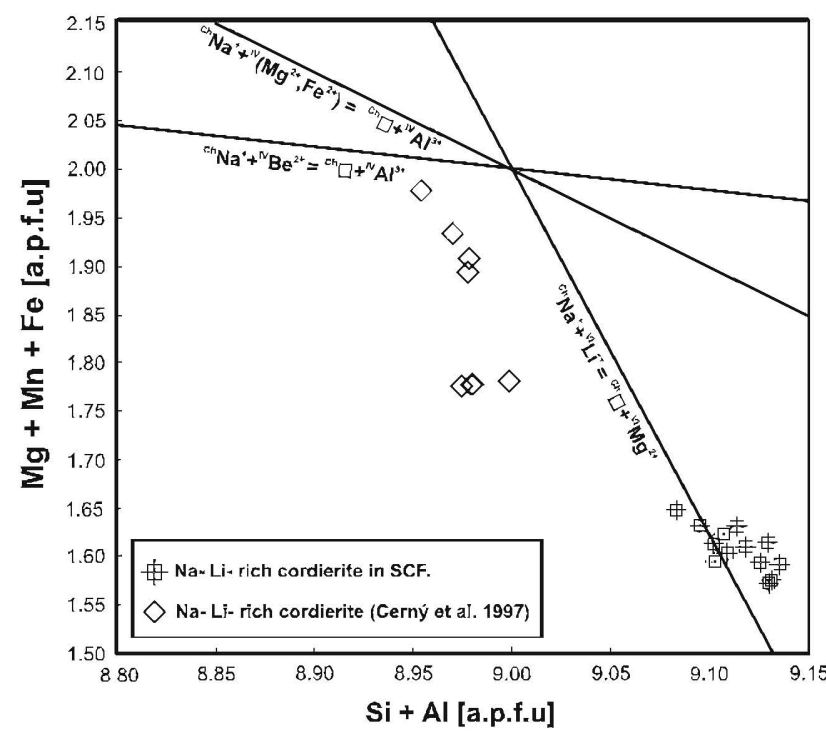

Fig. 5 Octahedral $(\mathrm{Mg}+\mathrm{Fe}+\mathrm{Mn})$ versus tetrahedral $(\mathrm{Si}+\mathrm{Al})$ site occupancy for natural cordierite, ignoring $\mathrm{Li}$ and $\mathrm{Be}$ in formula calculations (modified from Bertoldi et al. 2004). SCF Santa Cruz igneous facies

2. Textural evidence The primary texture of both minerals is masked by subsolidus replacement and overgrowth of andalusite and cordierite by muscovite. However, when these minerals are well preserved, they show features typical of igneous crystallization (Erdmann et al. 2004; Clarke et al. 2005), i.e. subhedral to euhedral shapes as opposed to allotriomorphic blastic cordierite, few or no mineral inclusions, absence of chiastolite inclusion in the andalusite, grain-size compatible with the magmatic rock-forming minerals of the Santa Cruz igneous facies, and appearance as homogeneously distributed isolated crystals (surrounded by muscovite). Remarkably, no peritectic texture such as reaction rims on $\mathrm{Al}$-rich minerals (e.g. garnet) or inclusions of high grade metamorphic minerals such as sillimanite were found.

3. Mineral chemistry Major element compositions of andalusite provide little information on the mineral origin. However, some information can be gained by checking for chemical equilibrium with other minerals (e.g. biotite, muscovite). The consistently high $\mathrm{Al}^{\mathrm{IV}}$ content of biotite in all the samples from the Santa Cruz igneous facies is consistent with crystallization in equilibrium with other Al-rich minerals such as andalusite, cordierite and muscovite, a circumstance well-known from other peraluminous rocks with magmatic cordierite or andalusite (e.g. Clarke et al. 2005; Dahlquist et al. 2005). On the other hand, the high $\mathrm{Na}_{2} \mathrm{O}$ and $\mathrm{MnO}$ contents of the Santa Cruz facies cordierite (Table 5) are remarkable and consistent with a magmatic origin (e.g. Gordillo et al. 1985; Secchi
Table 6 Representative analyses of the Santa Cruz igneous facies micas

\begin{tabular}{|c|c|c|c|c|}
\hline \multirow{2}{*}{$\begin{array}{l}\text { Mineral } \\
\text { Textural type } \\
\text { Analysis no. }\end{array}$} & \multirow{2}{*}{$\begin{array}{l}\text { Biotite } \\
\text { Av. }(n=5)\end{array}$} & \multicolumn{3}{|l|}{ Muscovite } \\
\hline & & $\begin{array}{l}\mathrm{Ms}_{\mathrm{a}} \\
\text { Av. }(n=3)\end{array}$ & $\begin{array}{l}\mathrm{Ms}_{\mathrm{b}} \\
33\end{array}$ & $\begin{array}{l}\mathrm{Ms}_{\mathrm{c}} \\
\text { Av. }(n=2)\end{array}$ \\
\hline \multicolumn{5}{|l|}{$\mathrm{wt} \%$} \\
\hline $\mathrm{SiO}_{2}$ & $35.09 \pm 0.28$ & $45.24 \pm 0.31$ & 45.04 & $45.76 \pm 0.10$ \\
\hline $\mathrm{TiO}_{2}$ & $2.42 \pm 0.27$ & $0.26 \pm 0.13$ & bdl & $0.04 \pm 0.02$ \\
\hline $\mathrm{Al}_{2} \mathrm{O}_{3}$ & $19.57 \pm 0.10$ & $36.09 \pm 0.26$ & 36.58 & $36.28 \pm 0.09$ \\
\hline $\mathrm{FeO}$ & $18.96 \pm 0.40$ & $1.03 \pm 0.10$ & 1.21 & $0.94 \pm 0.21$ \\
\hline $\mathrm{MnO}$ & $0.52 \pm 0.02$ & $0.03 \pm 0.02$ & 0.02 & $0.01 \pm 0.01$ \\
\hline $\mathrm{MgO}$ & $8.22 \pm 0.12$ & $0.76 \pm 0.05$ & 0.73 & $0.74 \pm 0.05$ \\
\hline $\mathrm{CaO}$ & $0.02 \pm 0.02$ & $0.02 \pm 0.02$ & 0.02 & $0.02 \pm 0.00$ \\
\hline $\mathrm{Na}_{2} \mathrm{O}$ & $0.08 \pm 0.03$ & $0.54 \pm 0.07$ & 0.46 & $0.44 \pm 0.03$ \\
\hline $\mathrm{K}_{2} \mathrm{O}$ & $9.60 \pm 0.17$ & $10.77 \pm 0.06$ & 10.90 & $10.98 \pm 0.19$ \\
\hline $\mathrm{F}$ & $0.27 \pm 0.05$ & $0.06 \pm 0.05$ & 0.02 & $0.03 \pm 0.03$ \\
\hline $\mathrm{Cl}$ & $0.04 \pm 0.01$ & 0.00 & 0.02 & bdl \\
\hline Total & $94.81 \pm 0.68$ & $94.77 \pm 0.73$ & 95.00 & $95.21 \pm 0.45$ \\
\hline O_F_Cl & $0.12 \pm 0.02$ & $0.02 \pm 0.02$ & 0.01 & $0.02 \pm 0.01$ \\
\hline CTotal & $94.69 \pm 0.67$ & $95.38 \pm 0.69$ & 94.99 & $95.20 \pm 0.43$ \\
\hline \multicolumn{5}{|c|}{ Structural formulae calculated on the basis of $22 \mathrm{O}$} \\
\hline $\mathrm{Si}$ & $5.39 \pm 0.05$ & $6.06 \pm 0.01$ & 6.03 & $6.10 \pm 0.00$ \\
\hline $\mathrm{Al}^{\mathrm{IV}}$ & $2.61 \pm 0.05$ & $1.94 \pm 0.01$ & 1.97 & $1.90 \pm 0.00$ \\
\hline Sum- $\mathrm{T}$ & 8.00 & 8.00 & 8.00 & 8.00 \\
\hline $\mathrm{Al}^{\mathrm{VI}}$ & $0.93 \pm 0.06$ & $3.76 \pm 0.03$ & 3.80 & $3.79 \pm 0.03$ \\
\hline $\mathrm{Ti}$ & $0.28 \pm 0.03$ & $0.03 \pm 0.01$ & 0.00 & 0.00 \\
\hline $\mathrm{Fe}^{2+}$ & $2.44 \pm 0.05$ & $0.12 \pm 0.01$ & 0.14 & $0.10 \pm 0.02$ \\
\hline Mn & $0.07 \pm 0.00$ & 0.00 & 0.00 & 0.00 \\
\hline $\mathrm{Mg}$ & $1.88 \pm 0.02$ & $0.15 \pm 0.01$ & 0.15 & $0.15 \pm 0.01$ \\
\hline Sum-B & 5.60 & 4.06 & 4.09 & 4.04 \\
\hline $\mathrm{Ca}$ & 0.00 & 0.00 & 0.00 & 0.00 \\
\hline $\mathrm{Na}$ & $0.02 \pm 0.01$ & $0.14 \pm 0.02$ & 0.12 & $0.11 \pm 0.01$ \\
\hline $\mathrm{K}$ & $1.88 \pm 0.02$ & $1.84 \pm 0.02$ & 1.86 & $1.87 \pm 0.03$ \\
\hline Sum-A & 1.90 & 1.98 & 1.98 & 1.98 \\
\hline $\mathrm{CF}$ & $0.26 \pm 0.05$ & $0.05 \pm 0.04$ & 0.02 & $0.03 \pm 0.02$ \\
\hline $\mathrm{CCl}$ & $0.02 \pm 0.01$ & 0.00 & 0.01 & 0.00 \\
\hline $\mathrm{Fe} /(\mathrm{Fe}+\mathrm{Mg})$ & $0.56 \pm 0.01$ & $0.43 \pm 0.02$ & 0.48 & $0.41 \pm 0.04$ \\
\hline
\end{tabular}

Total iron measured as FeO. Muscovite "a" and "b, c" (subscripts) correspond to primary and secondary muscovite, respectively (see text). Abbreviations mineral after Kretz (1983)

$b d l$ below detection limit

et al. 1991; Villaseca and Barbero 1994; Černý et al. 1997; Rapela et al. 2002; Erdmann et al. 2004; Dahlquist et al. 2005).

Trace elements provide complementary information on the origin of the minerals, particularly for the case of cordierite (e.g. Bea et al. 1994). The high Li content of the Santa Cruz facies cordierite suggests that this mineral crystallized from a Li-enriched magma. Moreover, chemical equilibrium of cordierite with 
Table 7 Representative LA-

ICP-MS analyses of the Santa Cruz igneous facies biotite

\begin{tabular}{|c|c|c|c|c|c|c|c|c|c|}
\hline \multirow{2}{*}{$\begin{array}{l}\text { Mineral } \\
\text { Analysis no. }\end{array}$} & \multicolumn{3}{|c|}{ Biotite 1} & \multicolumn{2}{|c|}{ Biotite 2} & \multicolumn{2}{|c|}{ Biotite 3} & \multicolumn{2}{|c|}{ Biotite 4} \\
\hline & 1 & 2 & 3 & 19 & 20 & 26 & 27 & 34 & 35 \\
\hline \multicolumn{10}{|l|}{$\mathrm{ppm}$} \\
\hline $\mathbf{L i}$ & 739 & 674 & 609 & 628 & 636 & 903 & 903 & 1,032 & 956 \\
\hline $\mathrm{Be}$ & 4.12 & 3.49 & 3.05 & 2.74 & 3.54 & 4.44 & 5.03 & 8.48 & 6.50 \\
\hline $\mathrm{Cs}$ & 876 & 700 & 639 & 44.0 & 55.5 & 178 & 93.0 & 754 & 304 \\
\hline $\mathrm{P}$ & 88.3 & 77.3 & 71.2 & 55.2 & 47.0 & 42.2 & 46.2 & 82.9 & 64.4 \\
\hline $\mathrm{Sc}$ & 12.4 & 9.49 & 8.16 & 27.6 & 32.6 & 16.6 & 24.2 & 8.54 & 10.8 \\
\hline $\mathrm{V}$ & 70.1 & 57.5 & 48.6 & 347 & 407 & 388 & 347 & 63.2 & 150 \\
\hline $\mathrm{Cr}$ & 2.38 & 3.06 & 1.79 & 132 & 136 & 76.8 & 99.3 & 2.84 & 28.8 \\
\hline $\mathrm{Co}$ & 22.8 & 19.5 & 17.1 & 20.0 & 18.7 & 31.2 & 30.4 & 23.3 & 24.5 \\
\hline $\mathrm{Ni}$ & 14.8 & 12.1 & 11.5 & 15.4 & 14.5 & 24.9 & 26.4 & 15.0 & 14.6 \\
\hline $\mathrm{Cu}$ & 1.82 & 1.34 & 1.65 & 2.18 & 3.78 & 0.62 & 3.48 & 0.84 & 0.50 \\
\hline $\mathrm{Zn}$ & 409 & 350 & 310 & 312 & 259 & 673 & 650 & 605 & 585 \\
\hline $\mathrm{Ga}$ & 37.8 & 32.7 & 29.7 & 37.0 & 33.8 & 64.0 & 57.5 & 34.4 & 26.7 \\
\hline $\mathrm{Rb}$ & 1,666 & 1,531 & 1,355 & 943 & 925 & 2,243 & 2,135 & 2,009 & 2,414 \\
\hline $\mathrm{Sr}$ & 3.96 & 4.71 & 5.61 & 7.22 & 5.09 & 0.65 & 0.97 & 0.90 & 0.75 \\
\hline $\mathrm{Y}$ & 0.54 & 0.59 & 0.71 & 0.50 & 0.68 & 0.03 & 0.04 & 0.10 & bdl \\
\hline $\mathrm{Zr}$ & 17.0 & 18.7 & 23.2 & 16.2 & 23.6 & 0.34 & 2.09 & 3.67 & 1.22 \\
\hline $\mathrm{Nb}$ & 110 & 96.3 & 88.0 & 107 & 105 & 261 & 213 & 126 & 312 \\
\hline $\mathrm{Ba}$ & 174 & 166 & 172 & 157 & 111 & 523 & 361 & 494 & 110 \\
\hline Hf & 0.12 & 0.23 & 0.03 & 0.46 & 0.62 & 0.08 & 0.12 & 0.09 & 0.10 \\
\hline $\mathrm{Ta}$ & 13.9 & 17.5 & 15.8 & 7.49 & 7.22 & 24.4 & 28.6 & 30.2 & 58.1 \\
\hline $\mathrm{Tl}$ & 10.6 & 9.77 & 8.16 & 5.92 & 6.32 & 11.3 & 10.7 & 10.0 & 10.5 \\
\hline $\mathrm{Pb}$ & 3.98 & 3.61 & 3.86 & 4.10 & 4.14 & 3.05 & 3.35 & 1.95 & 1.84 \\
\hline Th & 0.21 & 0.24 & 0.26 & 0.20 & 0.23 & bdl & bdl & 0.03 & $\mathrm{bdl}$ \\
\hline $\mathbf{U}$ & 0.37 & 0.35 & 0.43 & 0.25 & 0.41 & 0.05 & 0.19 & 0.04 & 0.06 \\
\hline \multicolumn{10}{|l|}{ REE (ppm) } \\
\hline $\mathrm{La}$ & 0.67 & 1.02 & 0.12 & 0.64 & 0.87 & 0.14 & 0.04 & 0.09 & 0.04 \\
\hline $\mathrm{Ce}$ & 0.79 & 1.10 & 0.15 & 1.14 & 1.35 & 0.21 & 0.04 & 0.10 & 0.06 \\
\hline Pr & 1.02 & 1.47 & 0.18 & 0.11 & 0.15 & 0.03 & bdl & bdl & bdl \\
\hline $\mathrm{Nd}$ & 0.45 & 0.55 & 0.05 & 0.48 & 0.67 & 0.04 & 0.02 & 0.09 & bdl \\
\hline $\mathrm{Sm}$ & 0.32 & 0.50 & 0.07 & 0.13 & 0.10 & bdl & bdl & bdl & bdl \\
\hline $\mathrm{Eu}$ & 2.19 & 3.55 & 0.38 & 0.04 & 0.02 & bdl & bdl & bdl & bdl \\
\hline $\mathrm{Gd}$ & 0.31 & 0.46 & 0.02 & 0.08 & 0.11 & bdl & bdl & 0.02 & 0.02 \\
\hline $\mathrm{Tb}$ & 0.52 & bdl & bdl & bdl & bdl & bdl & bdl & bdl & bdl \\
\hline Dy & bdl & bdl & bdl & bdl & bdl & bdl & bdl & bdl & 0.03 \\
\hline Ho & bdl & bdl & bdl & bdl & bdl & bdl & bdl & bdl & bdl \\
\hline $\mathrm{Er}$ & bdl & bdl & bdl & bdl & bdl & bdl & bdl & bdl & bdl \\
\hline $\operatorname{Tm}$ & bdl & bdl & bdl & bdl & bdl & bdl & bdl & bdl & bdl \\
\hline $\mathrm{Yb}$ & bdl & bdl & bdl & bdl & bdl & bdl & bdl & bd1 & bdl \\
\hline $\mathrm{Lu}$ & bdl & bdl & bdl & bdl & bdl & bdl & bdl & bdl & bdl \\
\hline
\end{tabular}

andalusite, biotite and primary muscovite in a magma is also suggested by the fact that the four minerals show high contents of trace elements such as $\mathrm{Li}, \mathrm{Rb}$, $\mathrm{Cs}, \mathrm{Zn}, \mathrm{Ga}$ and V.

4. Whole-rock chemistry The high ASI values (1.27-1.42; Table 2) of the Santa Cruz igneous facies suggest that the granitic magma was saturated in alumina, making precipitation of single cotectic grains of cordierite and andalusite highly probable (D'Amico et al. 1981; Gordillo et al. 1985; Clarke 1995; Dahlquist et al. 2005; Clarke et al. 2005 and references therein). In addition, Patiño Douce (1992) has shown that the activity coefficient of $\mathrm{Al}$ in silicic melts is a function of the alkali content of the melt, whereby alkali-rich 
Table 8 Representative LA-ICP-MS analyses of the Santa Cruz igneous facies muscovite

\begin{tabular}{|c|c|c|c|c|c|c|c|c|c|}
\hline \multirow{3}{*}{$\begin{array}{l}\text { Mineral } \\
\text { Analysis no. }\end{array}$} & \multicolumn{4}{|c|}{ Primary muscovite } & \multicolumn{5}{|c|}{ Secondary muscovite } \\
\hline & \multicolumn{2}{|c|}{ Muscovite 1} & \multicolumn{2}{|c|}{ Muscovite 2} & \multirow[b]{2}{*}{28 , after And } & \multirow[b]{2}{*}{ 9, after Crd } & \multirow[b]{2}{*}{ 10, after $\mathrm{Crd}$} & \multirow[b]{2}{*}{ 29, after Crd } & \multirow[b]{2}{*}{ 30, after Crd } \\
\hline & 4 & 5 & 14 & 15 & & & & & \\
\hline \multicolumn{10}{|l|}{ ppm } \\
\hline $\mathrm{Li}$ & 221 & 182 & 203 & 220 & 169 & 403 & 170 & 176 & 174 \\
\hline $\mathrm{Be}$ & 2.44 & 1.46 & 2.53 & 2.11 & 7.61 & 5.19 & 2.52 & 2.66 & 2.40 \\
\hline Cs & 88.1 & 55.0 & 70.8 & 74.1 & 77.7 & 128 & 38.6 & 64.5 & 55.8 \\
\hline $\mathbf{P}$ & 122 & 103 & 114 & 137 & 196 & 91.9 & 126 & 93.0 & 79.2 \\
\hline $\mathrm{Sc}$ & 36.3 & 5.88 & 8.27 & 7.69 & 22.2 & 2.18 & 2.23 & 7.26 & 5.11 \\
\hline V & 68.9 & 16.8 & 13.8 & 24.2 & 167 & 3.10 & 2.13 & 17.5 & 7.94 \\
\hline $\mathrm{Cr}$ & 2.85 & 0.60 & 25.4 & 2.23 & 40.9 & 0.98 & bdl & bdl & bdl \\
\hline Co & 1.08 & 1.02 & 0.88 & 0.96 & 1.24 & 4.15 & 0.70 & 0.98 & 0.86 \\
\hline $\mathrm{Ni}$ & 0.90 & 0.78 & 0.70 & 0.79 & 1.18 & 1.88 & 0.34 & 0.40 & 0.82 \\
\hline $\mathrm{Cu}$ & 0.86 & 3.37 & 1.08 & 2.23 & 1.47 & 1.73 & 1.15 & 0.10 & 0.13 \\
\hline $\mathrm{Zn}$ & 24.3 & 24.1 & 24.2 & 26.3 & 29.4 & 98.8 & 21.0 & 33.5 & 30.3 \\
\hline $\mathrm{Ga}$ & 86.1 & 78.9 & 82.0 & 81.0 & 98.7 & 66.7 & 76.5 & 66.6 & 66.7 \\
\hline $\mathrm{Rb}$ & 708 & 652 & 717 & 717 & 664 & 666 & 512 & 628 & 594 \\
\hline $\mathrm{Sr}$ & 6.58 & 7.53 & 7.11 & 7.10 & 3.93 & 6.01 & 8.66 & 5.72 & 6.27 \\
\hline $\mathrm{Y}$ & 0.35 & 0.35 & 0.22 & 0.16 & 0.87 & 0.17 & 0.41 & bdl & 0.02 \\
\hline $\mathrm{Zr}$ & 11.9 & 12.7 & 7.69 & 6.45 & 6.10 & 5.30 & 12.5 & 0.81 & 0.51 \\
\hline $\mathrm{Nb}$ & 77.5 & 31.6 & 29.9 & 29.2 & 70.2 & 4.59 & 1.59 & 12.8 & 6.40 \\
\hline $\mathrm{Ba}$ & 422 & 442 & 569 & 671 & 241 & 367 & 603 & 688 & 755 \\
\hline Hf & 0.18 & 0.05 & bdl & 0.24 & 0.37 & 0.02 & bdl & 0.07 & 0.01 \\
\hline $\mathrm{Ta}$ & 15.5 & 3.66 & 4.41 & 4.16 & 11.2 & 0.27 & 0.07 & 1.23 & 0.42 \\
\hline $\mathrm{T} 1$ & 3.54 & 2.98 & 3.53 & 3.75 & 2.79 & 4.31 & 2.68 & 2.58 & 2.38 \\
\hline $\mathrm{Pb}$ & 3.74 & 4.06 & 3.35 & 3.75 & 2.84 & 3.54 & 4.33 & 2.32 & 2.14 \\
\hline $\mathrm{Th}$ & 0.14 & 0.14 & 0.08 & 0.05 & 0.03 & 0.06 & 0.15 & bdl & bdl \\
\hline $\mathrm{U}$ & 0.21 & 0.23 & 0.10 & 0.11 & 0.31 & 0.22 & 0.21 & 0.02 & bdl \\
\hline \multicolumn{10}{|l|}{ REE (ppm) } \\
\hline $\mathrm{La}$ & 0.58 & 0.07 & bdl & 0.15 & 0.22 & bdl & bdl & bdl & bdl \\
\hline $\mathrm{Ce}$ & 0.68 & 0.19 & bdl & 0.30 & 0.22 & bdl & bdl & bdl & bdl \\
\hline Pr & 0.86 & 0.13 & bdl & 0.04 & bdl & bdl & bdl & bdl & bdl \\
\hline $\mathrm{Nd}$ & 0.29 & 0.05 & bdl & 0.18 & bdl & 0.05 & 0.22 & bdl & bdl \\
\hline $\mathrm{Sm}$ & 0.38 & 0.08 & 0.03 & 0.05 & bdl & bdl & bdl & bdl & bdl \\
\hline $\mathrm{Eu}$ & 1.87 & 0.42 & 0.03 & 0.05 & bdl & bdl & bdl & bdl & bdl \\
\hline $\mathrm{Gd}$ & 0.06 & 0.07 & bdl & 0.02 & bdl & bdl & bdl & bdl & bdl \\
\hline $\mathrm{Tb}$ & 0.01 & 0.08 & bdl & bdl & bdl & bdl & bdl & bdl & bdl \\
\hline Dy & 0.16 & 0.04 & bdl & 0.02 & bdl & bdl & bdl & bdl & bdl \\
\hline Ho & 0.22 & bdl & bdl & bdl & bdl & bdl & bdl & bdl & bdl \\
\hline Er & 0.49 & bdl & bdl & bdl & bdl & bdl & bdl & bdl & bdl \\
\hline $\operatorname{Tm}$ & bdl & bdl & bdl & bdl & bdl & bdl & bdl & bdl & bdl \\
\hline $\mathrm{Yb}$ & 0.02 & bdl & bdl & bdl & bdl & bdl & bdl & bdl & bdl \\
\hline $\mathrm{Lu}$ & bdl & bdl & bdl & bdl & bdl & bdl & bdl & bdl & bdl \\
\hline
\end{tabular}

Abbreviations mineral after Kretz (1983). Muscovite 1 and 2 correspond to different analyzed mineral grains bdl below detection limit

andalusite ( $\mathrm{P}^{\prime}$, Fig. 7), better allows for andalusite crystallization prior to primary muscovite formation (field $\mathrm{A}^{\prime}$; Fig. 7). Moreover, the field for potentially magmatic andalusite is even larger and probably more realistic, if the Richardson et al. (1969) andalusite-sillimanite equilibrium curve is considered (Fig. 7; curve R69). 
Table 9 Geothermobarometry for the La Costa pluton

\begin{tabular}{lll}
\hline Calibration method & Mineral assemblage $/$ \\
Zr concentration $(\mathrm{ppm})$ & $\frac{P, T \text { values }}{T\left({ }^{\circ} \mathrm{C}\right) \quad}$ & $P(\mathrm{kbar})( \pm 0.1)$
\end{tabular}

Anillaco igneous facies, sample ANI-03

Ganguly and Saxena (1984)

Hoisch (1990) R2 model

Hoisch (1990) R4 model

Santa Cruz igneous facies
Grt-Bt

Grt-Bt-P1-Qtz

Grt-Bt-Ms-P1-Qtz $733^{\mathrm{a}}$

1.9

1.8

Zircon saturation temperature $\left(T_{Z \mathbf{r}}\right)^{\mathrm{b}}$

$99^{c}$

758

Composition of the Anillaco facies gamet (analysis number 14-15-16-21-22-23), biotite (45-46-47-48), muscovite (37-38-39-40-49) and plagioclase (29-30-31-33) in the calculations are mean values from Alasino (2007)

a See uncertainty discussion in Ganguly and Saxena (1984) and Anderson (1996)

b $T_{\mathrm{Zr}}=12,900 /\left[2.95+0.85 M+\ln \left(476,000 / \mathrm{Zr}_{\text {melt }}\right)\right]$, where $D^{\mathrm{Zr}, \text { ircon } / \text { melt }}=\left(476,000 / \mathrm{Zr}_{\text {melt }}\right)$ is the ratio of $\mathrm{Zr}$ concentration (ppm) in zircon to that in the saturated melt; $\mathrm{M}$ is a compositional factor that accounts for dependence of zircon solubility on $\mathrm{SiO}_{2}$ content and peraluminosity of the melt $[(\mathrm{Na}+\mathrm{K}+2 \mathrm{Ca}) / \mathrm{Al} \times \mathrm{Si}$ ), all values as cation fractions] (Watson and Harrison 1983 with rearranging after Miller et al. 2003)

c Zirconium concentration in the Santa Cruz igneous facies from the average of Table 2

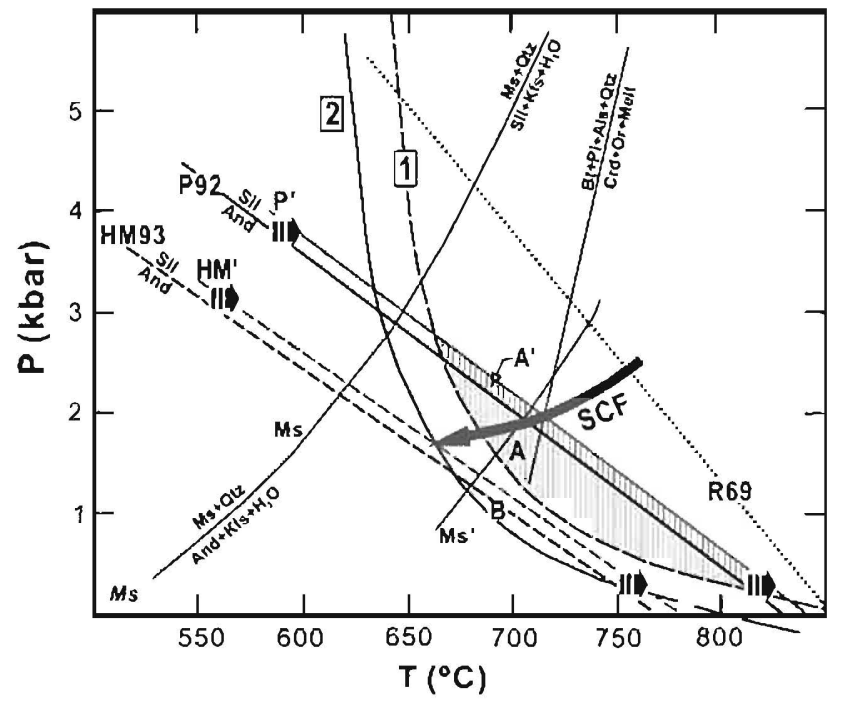

Fig. $7 P-T$ projection illustrating the relationship between the granite solidus, the And-Sill boundary and the Ms + Qtz stability field. $S C F$ hypothetical Santa Cruz igneous facies $P-T$ path. A Field for Al-silicate crystallization prior to primary Ms crystallization, bounded by the wet granite solidus and the And-Sill equilibrium curve P92. $A^{\prime}$ the And + melt field is bounded by the wet granite solidus and the AndStill equilibrium curve $P^{\prime} . B$ the And + melt field is bounded by the $\mathrm{Al}_{2} \mathrm{O}_{3}$-saturated granite solidus and the And-Still equilibrium curve $\mathrm{HM}^{\prime} .1$ Wet granite solidus (Johannes and Holtz 1996), $2 \mathrm{Al}_{2} \mathrm{O}_{3^{-}}$ saturated granite solidus (Johannes and Holtz 1996), R69 Richardson et al. (1969), P92 And-Still boundary (Pattison 1992), HM93 And-Still boundary (Holdaway and Mukhopadhyay 1993). $H M^{\prime}$ and $P^{\prime}$ Shifting of the And-Still boundary (Holdaway and Mukhopadhyay 1993 and Pattison 1992, repectively) due to the $\mathrm{Fe}^{3+}$ content of andalusite (see text). $M s^{\prime}$ empirical equilibrium curve for the reaction: $\mathrm{Ms}+\mathrm{Qtz}=\mathrm{Kfs}+\mathrm{Al}$-silicates $+\mathrm{H}_{2} \mathrm{O} / \mathrm{Melt}$ (D'Amico et al. 1981). Experimental curves for the reaction $\mathrm{Ms}+\mathrm{Qtz}=\mathrm{Kfs}+\mathrm{Al}$-silicates $+\mathrm{H}_{2} \mathrm{O} /$ Melt and $\mathrm{Bt}+\mathrm{Pl}+$ Al-silicates $+\mathrm{Qtz}=\mathrm{Crd}+$ Or + Melt are from Pattison and Tracy (1991)

\section{Cordierite}

Textural evidence, along with whole-rock and mineral chemical compositions, suggests that $\mathrm{Na}$ - and $\mathrm{Li}$-rich cordierite of the Santa Cruz igneous facies crystallized from a peraluminous magma, and that it was at some stage in equilibrium with andalusite (see also Clarke 1995; Erdmann et al. 2004; Clarke et al. 2005; Dahlquist et al. 2005). The chemical composition of the Na- and Li-rich cordierite is consistent with the whole-rock chemistry of the Santa Cruz monzogranite. This granitoid has $\mathrm{SiO}_{2}$ content (65.3-68.6 wt\%; Table 2) remarkably lower than other two other granitic facies of the La Costa pluton (ca. 74 wt\%; Alasino et al. 2006). However, the contents of alkalis and other incompatible elements such as $\mathrm{Li}, \mathrm{Be}, \mathrm{Rb}$ and $\mathrm{Cs}$ in the Santa Cruz monzogranite are high relative to its silica content (Table 2). It seems that melt composition is the most important single factor controlling mineral/melt partition coefficients. The best constraints on mineral/melt partition coefficients in a low-pressure peraluminous anatectic system are those of Bea et al. (1994), who estimate crystal/melt partition coefficients as the concentration ratios between peraluminous leucosomes (interpreted as pure melts) and mesosome minerals, using a laser probe coupled to an ICP mass spectrometer. These authors demonstrate that cordierite crystallizing in peraluminous magmas strongly fractionates $\mathrm{Li}, \mathrm{Be}, \mathrm{Rb}$ and $\mathrm{Cs}$, and is thus an efficient crystalline reservoir for these elements in magmas strongly enriched in aluminium, at crystallization temperatures of $\sim 750^{\circ} \mathrm{C}$, similar that observed for the Santa Cruz igneous facies. 
Argentina. PhD Thesis, Universidad Nacional de Córdoba (unpblished), Argentina, p 576

1. The Santa Cruz igneous facies of the La Costa pluton is an S-type granitoid with andalusite, Na- and Li-rich cordierite and primary muscovite. Petrography, mineral chemistry and whole-rock chemistry support magmatic crystallization for all three minerals. Secondary low- $T$ muscovite formed under subsolidus conditions, largely after andalusite and $\mathrm{Na}$ - and Li-rich cordierite.

2. The Santa Cruz igneous facies crystallized at a moderate depth (ca. $1.9 \mathrm{kbar}$ ). At this pressure, crystallization of primary muscovite was favored by both depression of the granite solidus due to $\mathrm{Al}$ saturation, and the fluxing effect of $\mathrm{B}, \mathrm{Li}$ and $\mathrm{P}$ in the magma. Moreover, the stability field of muscovite (+quartz) was probably significantly increased relative to the experimental one. Andalusite crystallization from the magma at pressure of ca. $2 \mathrm{kbar}$ implies that the more realistic And-Sill boundary should be that of Pattison (1992) or that of Richardson et al. (1969). Upward shifting by ca. $13^{\circ} \mathrm{C}$ of the boundary due to $\mathrm{Fe}^{3+}$ content in andalusite also contributed to expansion of the andalusite stability field.

3. High Na and Li contents in cordierite are reported for the first time from a relatively low-silica monzogranite. Magma composition was relatively rich in incompatible elements, leading to crystallization of Na-rich cordierite markedly enriched in $\mathrm{Li}$ (654-3,043 ppm) and Be (82$1,879 \mathrm{ppm}$ ); the micas also show enrichment in some trace elements, such as $\mathrm{Rb}, \mathrm{Li}, \mathrm{Cs}, \mathrm{Ba}, \mathrm{Nb}, \mathrm{Zn}, \mathrm{V}, \mathrm{P}$ and Sc. Contents of trace elements in andalusite are low except for $\mathrm{P}, \mathrm{V}, \mathrm{Li}$ and $\mathrm{Ga}$.

4. Substitution in the unusual $\mathrm{Na}$ - and Li-rich cordierites was of the type: ${ }^{{ }^{C h}} \mathrm{Na}^{+}+{ }^{{ } I} \mathrm{Li}^{+}={ }^{C h}[]+{ }^{{ } I} \mathrm{Mg}^{2+}$, leading to almost complete occupancy of the octahedral sites.

Acknowledgments Funds were provided by grants IM-40 2000 (ANPCyT, Argentina), Spanish MEC grant CGL2005-02065/BTE and Universidad Complutense-CAM grant 910495 (2007). We are grateful to C. Villaseca (UCM) for critical review of an earlier draft of this manuscript and to R. Pankhurst (BGS) and P. Searles (CRILARCONICET) for revision of the English version of the text. Technical support from CRILAR-CONICET in the preparation of the manuscript is acknowledged. We thank Raúl Lira, Jinhai Yu, Marlina A. Elburg and Wolf-Christian Dullo for insightful and constructive reviews.

\section{References}

Alasino P (2007) Geología, petrología y geoquímica de los granitoides Famatinianos ubicados en el sector occidental, y su comparación con el sector central, a los $29^{\circ}$ de latitud sur del margen proto-andino de Gondwana, Sierras Pampeanas,

Alasino PH, Dahlquist JA, Galindo C, Baldo E, Casquet C (2005) Granitoides peraluminosos con andalucita y cordierita magmáticas en la sierra de Velasco: implicancias para el Orógeno Famatiniano. In: Dahlquist JA, Baldo EG, Alasino PH (eds) Geología de la provincia de La Rioja (Precámbrico-Paleozoico Inferior). Rev Asoc Geol Arg D8:109-122

Alasino PH, Dahquist JA, Galindo C, Casquet C (2006) Plutón La Costa, una expresión de magmatismo tipo-S en el sector noreste de la sierra de Velasco, Sierras Pampeanas, Argentina. Rev Asoc Geol Argent 61:161-170

Allen PL, Barr SM (1983) The Ellison Lake Pluton: a cordieritebearing monzogranitic intrusive body in southwestem Nova Scotia. Can Mineral 21:583-590

Anderson L (1996) Status of thermobarometry in granitic batholiths. Trans R Soc Edinb Earth 87:125-138

Bea F, Pereira MD, Stroh A (1994) Mineral/leucosome trace-element partitioning in a peraluminous migmatite (a laser ablation-ICPMS study). Chem Geol 117:291-312. doi:10.1016/0009-2541 (94) $90133-3$

Bellido F, Barrera J (1979) Nódulos cordieríticos en el granito de La Cabrera (Sistema Central español). Estud Geol 35:279-284

Bertoldi C, Proyer A, Garbe-Schönberg D, Behrens H, Dachs E (2004) Comprehensive chemical analyses of natural cordierites: implications for exchange mechanisms. Lithos 78:389-409. doi: 10.1016/j.lithos.2004.07.003

Černý P, Povondra P (1966) Beryllian cordierite from Vezna: (Na, K) + Be $\rightarrow$ Al. Neues Jahrb Miner Monatsh 44:36-44

Černý P, Chapman R, Schreyer W, Ottolini L, Bottazzi P, McCammon CA (1997) Lithium in sekaninaite from the type locality, Dolni Bory, Czech Republic. Can Mineral 35:167-173

Cesare B, Marchesi C, Hermann J, Gómez-Pugnaire MT (2003) Primary melt inclusions in andalusite from anatectic graphitic metapelites: implications for the $\mathrm{Al}_{2} \mathrm{SiO}_{5}$ triple point. Geology 31:573-576. doi:10.1130/0091-7613(2003)031<0573:PMПAF $>2.0 . \mathrm{CO} ; 2$

Clarke DB (1995) Cordierite in felsic igneous rocks: a synthesis. Mineral Mag 59:311-325. doi:10.1180/minmag.1995.059.395.15

Clarke DB, McKenzie CB, Muecke GK, Richardson SW (1976) Magmatic andalusite from the South Mountain Batholith, Nova Scotia. Contrib Mineral Petrol 56:279-287. doi:10.1007/ BF00466826

Clarke DB, Dorais M, Barbarin B, Barker D, Cesare B, Clarke G, el Baghdadi M, Erdmann S, Förster H-J, Gaeta M, Gottesmann B, Jamieson RA, Kontak DJ, Koller F, Gomes CL, London D, Morgan Vi GB, Neves LJPF, Pattison DRM, Pereira AJSC, Pichavant M, Rapela C, Renno AD, Richards S, Roberts M, Rottura A, Saavedra J, Sial AN, Toselli AJ, Ugidos JM, Uher P, Villaseca C, Visonà D, Whitney DL, Williamson B, Woodard HH (2005) Occurrence and origin of andalusite in peraluminous felsic igneous rocks. J Petrol 46:441-472. doi:10.1093/petrology/egh083

Clemens JD, Wall VJ (1981) Origin and crystallization of some peraluminous (S-type) granitic magmas. Can Mineral 19:111-131

D'Amico C, Rottura A, Bargossi GM, Nannetti MC (1981) Magmatic genesis of andalusite in peraluminous granites. Examples from Eisgarn Type granites in Moldanubiken. Rend Soc Ital Mineral Petrol 38:15-25

Dahlquist JA, Rapela CW, Baldo E (2005) Petrogenesis of cordienitebearing S-type granitoids in Sierra de Chepes, Famatinian orogen, Argentina. J S Am Earth Sci 20:231-251. doi:10.1016/ j.jsames.2005.05.014

Dahlquist JA, Galindo C, Pankhurst RJ, Rapela CW, Alasino PH, Saavedra J, Fanning CM (2007) Magmatic evolution of the Peñón Rosado granite: petrogenesis of garnet-bearing granitoids. Lithos 95:177-207. doi:10.1016/j.lithos.2006.07.010 
Didier J, Dupraz J (1986) Magmatic and metasomatic cordierite in the Velay granitic massif. In: Augusthitis A (ed) The Crust: the significance of granite-gneisses in the lithosphere. Theophrastus, Athens, pp 35-77

Erdmann S, Clarke DB, MacDonald MA (2004) Origin of chemically zoned and unzoned cordierites from the South Montain and Musquodoboit Batholiths, Nova Scotia. Trans R Soc Edinb Earth 95:99-110. doi:10.1017/S0263593304000112

Evensen JM, London D (2003) Experimental partitioning of Be, Cs, and other trace elements between cordierite and felsic melt, and the chemical signature of S-type granite. Contrib Mineral Petrol 144:739-757

Flood RH, Shaw SE (1975) A cordierite-bearing granite suite from the New England batholith, N.S.W., Australia. Contrib Mineral Petrol 52:157-164. doi:10.1007/BF00457291

Ganguly J, Saxena SK (1984) Mixing properties of aluminosilicate garnets: constraints from natural and experimental data, and applications to geothermo-barometry. Am Mineral 69:88-97

Georget Y, Fourcade S (1988) REE partitioning in magmatic cordierite: implications for cordierite-bearing granitoids as exemplified by the Huelgoat intrusion (Brittany, France). Neues Jahrb Miner Abh 158:225-240

Gordillo CE, Schreyer W, Werding G, Abraham K (1985) Lithium in NaBe-cordierites from El Peñón, Sierra de Córdoba, Argentina. Contrib Mineral Petrol 90:93-101. doi:10.1007/BF00373045

Gottesmann B, Förster H-J (2004) Sekaninaite from the Satzung granite (Erzgebirge, Germany): magmatic or xenolithic? Eur J Mineral 16:483-491. doi:10.1127/0935-1221/2004/0016-0483

Grambling JA, Williams ML (1985) The effect of $\mathrm{Fe}^{3+}$ and $\mathrm{Mn}^{3+}$ on aluminium silicate phase relations in north-central New Mexico, USA. J Petrol 26:324-354

Höckenreiner M, Söllner F, Miller H (2003) Dating the TIPA shear zone: an early Devonian terrane boundary between the Famatinian and Pampean systems (NW Argentina). J S Am Earth Sci 16:45-66. doi:10.1016/S0895-9811(03)00018-X

Hoisch TD (1990) Empirical calibration of six geobarometers for the mineral assemblage quartz + muscovite + biotite + plagioclase + gamet. Contrib Mineral Petrol 104:225-234. doi:10.1007/ BF00306445

Holdaway MJ, Mukhopadhyay B (1993) Stability of andalusite and the aluminosilicate phase diagram. Am J Sci 271:97-131

Jarosewich E, Nelen JA, Norberg JA (1980) Reference samples for electron microprobe analysis. Geostand Newsl 4:43-47. doi: 10.1111/j.1751-908X.1980.tb00273.x

Johannes W, Holtz F (1996) Petrogenesis and Experimental Petrology of Granitic Rocks. Springer-Verlag, Berlin

Kawakami T (2002) Magmatic andalusite from the migmatite zone of the Aoyama area, Ryoke metamorphic belt, SW Japan, and its importance in constructing the P-T path. J Mineral Petrol Sci 97:241-253. doi: $10.2465 /$ jmps.97.241

Kerrick DM, Speer JA (1988) The role of minor element solid solution on the andalusite-sillimanite equilibrium in metapelites and peraluminous granitoids. Am J Sci 288:152-192

Kretz R (1983) Symbols for rock-forming minerals. Am Mineral $68: 277-279$

Larson T, Sharp Z (2003) Stable isotope constraints on the $\mathrm{Al}_{2} \mathrm{SiO}_{5}$ "triple-point" rocks from the Proterozoic Priest pluton contact aureole, New Mexico. J Metamorph Geol 21:785-798. doi: 10.1046/j.1525-1314.2003.00481.x

London D (1995) Geochemical features of peraluminous granites, pegmatites, and rhyolites as sources of lithophile metal deposits. In: Thompson JFH (ed) Magmas, fluids, and ore deposits. Short Course Handbook, Mineralogical Association of Canada, vol 23, pp 175-202

López JP, Toselli AJ (1993) La faja milonítica TIPA: faldeo oriental del Sistema de Famatina, Argentina. XII Congreso Geológico Argentino 3:39-42
McGuire AV, Francis CA, Diar MD (1992) Mineral standards for electron microprobe analysis of oxygen. Am Mineral 77:10871091

Miller CF, Stoddard EF (1981) The role of manganese in the paragenesis of magmatic gamet: an example from the old Woman Piute Range, California. J Geol 89:233-246

Miller CF, Stoddard EF, Bradfish LJ, Dollase WA (1981) Composition of plutonic muscovite. Genetic implications. Can Mineral 19:25-34

Miller CF, McDowell SM, Mapes RW (2003) Hot and cold granites? Implications of zircon saturation temperatures and preservation of inheritance. Geology 31:529-532. doi:10.1130/0091-7613 (2003) $031<0529:$ HACGIO $>2.0 . \mathrm{CO} ; 2$

Patiño Douce AE (1992) Calculated relationships between activity of alumina and phase assemblages of silica-saturated igneous rocks. Petrogenetic implications of magmatic cordierite, gamet and aluminosilicate. J Volcanol Geotherm Res 52:43-63. doi: 10.1016/0377-0273(92)90132-W

Pattison DRM (1992) Stability of andalusite and sillimanite and the $\mathrm{Al}_{2} \mathrm{SiO}_{5}$ triple point: constraints from the Ballachulisch aureole, Scotland. J Geol 100:423-446

Pattison DRM, Tracy RJ (1991) Phase equilibria and thermobarometry of metapelites. In: Kerrick DM (ed) Contact metamorphism. Rev Mineral, vol 26, pp 105-206

Phillips GN, Wall VJ, Clemens JD (1981) Petrology of the Strathbogie batholith: a cordierite-bearing granite. Can Mineral 19:47-63

Rapela CW, Baldo EG, Pankhurst RJ, Saavedra J (2002) Cordieritite and leucogranite formation during emplacement of highly peraluminous magma: the El Pilón Granite Complex (Sierras Pampeanas, Argentina). J Petrol 43:1003-1028. doi:10.1093/ petrology/43.6.1003

Richardson SW, Gilbert MC, Bell PM (1969) Experimental determination of kyanite-andalusite and andalusite-sillimanite equilibria: the aluminium silicate triple point. Am J Sci 267:259-272

Schreyer W (1985) Experimental studies on cation substitutions and fluid incorporation in cordierite. Bull Mineral (Paris) 108:273-291

Secchi FA, Brotzu P, Callegari E (1991) The Arburese igneous complex (SW Sardinia, Italy) - an example of dominant igneous fractionation leading to peraluminous cordierite-bearing leucogranites as residual melts. Chem Geol 92:213-243. doi:10.1016/ 0009-2541(91)90057-X

Speer JA (1984) Micas in igneous rocks. Rev Mineral 13:299-356

Statacorp (2005) STATA statistical software: release 9. Statacorp LP, College Station, TX

Stimac JA, Clark AH, Chen Y, Garcia S (1995) Enclaves and their bearing on the origin of the Cornubian batholith, southwest England. Mineral Mag 59:273-296

Ugidos JM, Recio C (1993) Origin of cordierite-bearing granites by assimilation in the Central Iberian Massif (CIM), Spain. Contrib Mineral Petrol 98:27-43

Villaseca C, Barbero L (1994) Chemical variability of Al-Ti-Fe-Mg minerals in peraluminous granitoids rocks from central Spain. Eur J Mineral 6:691-710

Watson EB, Harrison TM (1983) Zircon saturation revisited: temperature and composition effects in a variety of crustal magma types. Earth Planet Sci Lett 64:295-304. doi:10.1016/ 0012-821X(83)90211-X

Weber C, Pichavant M, Barbey P (1985) La cordierite dans 1e domaine anatectique du Velay (Massif Central Français): un marqueur de I'anatexie, du magmatisme et de I'hydrothermalisme. Compt Rend Acad Sci Paris 301:303-308

Zeck HP, Williams IS (2002) Inherited and magmatic zircon from Neogene Hoyazo cordierite dacite, SE Spain-Anatectic source rock provenance and magmatic evolution. J Petrol 43:10891104. doi:10.1093/petrology/43.6.1089 